Chatterjee, Kuntal; Dopfer, Otto

\title{
Microhydration Structures of Protonated Oxazole
}

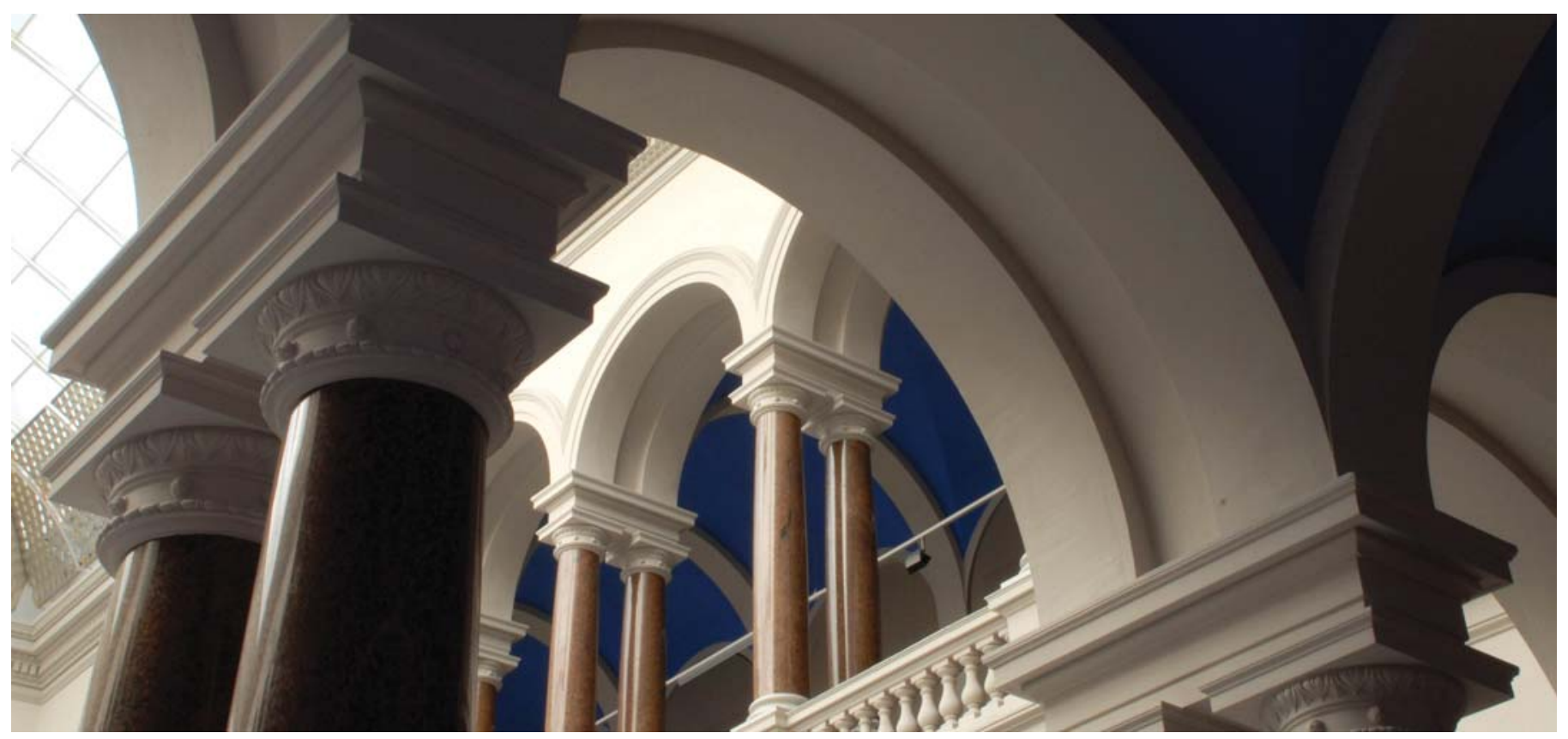

Chatterjee, K., \& Dopfer, O. (2019). Microhydration Structures of Protonated Oxazole. The Journal of Physical Chemistry A. https://doi.org/10.1021/acs.jpca.9b06587 


\title{
Microhydration Structures of Protonated Oxazole
}

\author{
Kuntal Chatterjee and Otto Dopfer* \\ Institut für Optik und Atomare Physik, TU Berlin, Hardenbergstr. 36, 10623 Berlin, Germany
}

*Corresponding author: dopfer@physik.tu-berlin.de

\begin{abstract}
The initial microhydration structures of the protonated pharmaceutical building block oxazole $(\mathrm{Ox}), \mathrm{H}^{+} \mathrm{Ox}$ $\mathrm{W}_{n \leq 4}$, are determined by infrared photodissociation (IRPD) spectroscopy combined with quantum chemical dispersion-corrected density functional theory calculations (B3LYP-D3/aug-cc-pVTZ). Protonation of Ox, achieved by chemical ionization in an $\mathrm{H}_{2}$-containing plasma, occurs at the most basic $\mathrm{N}$ atom. The analysis of systematic shifts of the $\mathrm{NH}$ and $\mathrm{OH}$ stretch vibrations as a function of the cluster size provides a clear picture for the preferred cluster growth in $\mathrm{H}^{+} \mathrm{Ox}-\mathrm{W}_{n}$. For $n=1-3$, the IRPD spectra are dominated by a single isomer, and microhydration of $\mathrm{H}^{+} \mathrm{Ox}$ with hydrophilic protic $\mathrm{W}$ ligands occurs by attachment of a hydrogenbonded (H-bonded) $\mathrm{W}_{n}$ solvent cluster to the acidic $\mathrm{NH}$ group via $\mathrm{NH}$... O H-bond. Such $\mathrm{H}$-bonded networks are stabilized by strong cooperativity effects. This is in contrast to previously studied hydrophobic ligands, which prefer internal ion solvation. The strength of the $\mathrm{NH}$... O ionic $\mathrm{H}$-bond increases with the degree of hydration because of the increasing proton affinity (PA) of the $\mathrm{W}_{n}$ cluster. At $n=4$, proton-transferred structures of the type $\mathrm{Ox}-\mathrm{H}^{+} \mathrm{W}_{n}$ become energetically competitive with $\mathrm{H}^{+} \mathrm{Ox}-\mathrm{W}_{n}$ structures, because differences in solvation energies can compensate for the differences in the PAs, and barrierless proton transfer from $\mathrm{H}^{+} \mathrm{Ox}$ to the $\mathrm{W}_{n}$ solvent subcluster becomes feasible. Indeed, the IRPD spectrum of the $n=4$ cluster is more complex suggesting the presence of more than one isomer, although it lacks unequivocal evidence for the predicted intracluster proton transfer.
\end{abstract}

Revised version submitted to J. Phys. Chem. A on August 6 (2019) 


\section{Introduction}

Hydration of biomolecules is a fundamental chemical process that regulates their stability, flexibility, and function. As a result, solvating water layers are nowadays considered as an integral part of such bioactive macromolecules. ${ }^{1-10}$ The absence of water often leads to inactivity of proteins and nucleic acids. In general, biological macromolecules bind to the solvating surface water ligands (often called "biological" water) through extended hydrogen bonded ( $\mathrm{H}$-bonded) networks, which are pivotal to the recognition of various drugs and proteins. ${ }^{11-16}$ Experimentally, a number of prudent techniques, including $X$-ray diffraction, nuclear magnetic resonance, and neutron scattering, have been employed in the condensed phase to understand the impact of hydration on the inherent physical and chemical properties of the bioactive species. ${ }^{10}$ However, most of these strategies suffer from macroscopic solvent effects, interactions with other molecules and substrates, and thermal and heterogeneous broadening, which prevent the determination of intrinsic fundamental biochemical characteristics of such molecules and the structure and dynamics of individual water molecules in the first hydration layer. ${ }^{10,17}$ These problems can be circumvented by interrogating individual molecules and clusters in the gas phase. ${ }^{10,17-26}$ The spectroscopic study of mass-selected clusters in combination with high-level quantum chemical calculations provides detailed information about the intrinsic molecular properties of the solute molecules and their changes upon sequential addition of individual solvent molecules.

Herein, we address the microhydration of protonated oxazole $\left(\mathrm{H}^{+} \mathrm{Ox}\right)$, which is an important biomolecular building block of numerous pharmaceutical and natural products, exhibiting antibiotic, antitumor, antituberculosis, antiinflammatory, and HIV-inhibitory properties. ${ }^{27-36}$ Amino acids with an Ox nucleus are extensively used to modify the bioactivity of various macromolecules. ${ }^{27,28,37-43}$ It is well established that the structure and reactivity of such molecules are often regulated by solvation, substitution, and protonation of the fundamental building blocks like Ox. For example, protonation of the Ox ring of the acetyl-coenzyme $A$ carboxylase (ACCase) inhibitor, Metamifop, influences its binding efficiency with that particular enzyme. ${ }^{44}$

The structure and vibrations of neutral $\mathrm{Ox}$ in its planar ground electronic state have been explored by microwave, infrared (IR), and Raman spectroscopy, as well as quantum chemical calculations. ${ }^{45-53}$ No experimental information is available for any cluster of Ox. Low-level calculations predict for the neutral Oxwater $(\mathrm{Ox}-\mathrm{W})$ dimer hydration at the $\mathrm{N}$ center of $\mathrm{Ox}$ via a $\mathrm{OH}$... N H-bond, because the two lone pairs of the $\mathrm{O}$ atom of $\mathrm{Ox}$ participate in $\pi$ conjugation of the aromatic ring and thus are less efficient $\mathrm{H}$-bond acceptors. ${ }^{49}$ The Ox ${ }^{+}$radical cation has been characterized by photoelectron spectroscopy, ${ }^{54,55}$ and an accurate adiabatic ionization energy and several vibrational frequencies of the planar cation ground state are available from a high-resolution mass-analyzed threshold ionization spectrum. Photoelectron imaging of the oxazolide anion demonstrates selective deprotonation from the $\mathrm{C} 2$ position of the hetrocyclic ring. ${ }^{56}$

Information about $\mathrm{H}^{+} \mathrm{Ox}$ and its clusters is scarce. Computations suggest exclusive $\mathrm{N}$-protonation of the aromatic ring, ${ }^{57,58}$ and the the recommended value for the proton affinity is tabulated as $P A=876.4 \mathrm{~kJ} / \mathrm{mol} .{ }^{59}$ Recently, we reported IR spectra of $\mathrm{H}^{+} \mathrm{Ox}-\mathrm{L}_{n}$ clusters with $\mathrm{L}=\mathrm{Ar}(n \leq 2)$ and $\mathrm{N}_{2}(n \leq 4)$ obtained by IR photodissociation (IRPD) of mass-selected clusters generated in a molecular plasma expansion. ${ }^{60}$ Analysis of these spectra by dispersion-corrected density functional theory calculations at the B3LYP-D3/aug-cc- 
pVTZ level provided the first spectroscopic proof that protonation of Ox indeed occurs exclusively at the $\mathrm{N}$ atom. In addition, the results yielded a first impression of the solvation process of $\mathrm{H}^{+} \mathrm{Ox}$ with aprotic hydrophibic ligands, which occurs by the formation of linear and bifurcated $\mathrm{NH} \ldots \mathrm{L}$ and $\mathrm{NH} \ldots \mathrm{L}_{2}$ bonds followed by further interior ion solvation. ${ }^{60}$ Herein, we employ the same combined spectroscopic and computational approach to extend these studies on $\mathrm{H}^{+} \mathrm{Ox}-\mathrm{L}_{n}$ clusters to dipolar ligands, namely $\mathrm{L}=W=\mathrm{H}_{2} \mathrm{O}$ and $n \leq 4$, to characterize the differences of solvation of $\mathrm{H}^{+} \mathrm{Ox}$ in a protic hydrophilic environment, which is relevant for understanding hydration effects of the protonated Ox building block in pharmaceutical applications.

\section{Experimental Section}

IRPD spectra of mass-selected $\mathrm{H}^{+} \mathrm{Ox}-\mathrm{W}_{n \leq 4}$ and tagged $\mathrm{H}^{+} \mathrm{Ox}-\mathrm{W}_{n \leq 2}-\mathrm{N}_{2}$ clusters are recorded in the $\mathrm{XH}$ stretch range $(\mathrm{X}=\mathrm{C}, \mathrm{N}, \mathrm{O})$ in a tandem quadrupole mass spectrometer coupled to an electron ionization (EI) source and an octupole ion guide. ${ }^{61,62}$ Briefly, $\mathrm{H}^{+} \mathrm{Ox}-\mathrm{W}_{n}\left(-\mathrm{N}_{2}\right)$ clusters are produced in an ion source, which combines a pulsed supersonic expansion with electron and chemical ionization close to nozzle orifice. The expanding gas mixture is generated by seeding $\mathrm{Ox}\left(\mathrm{C}_{3} \mathrm{H}_{3} \mathrm{NO}\right.$, Sigma-Aldrich, $98 \%$, heated to $\left.328 \mathrm{~K}\right)$ and $\mathrm{H}_{2} \mathrm{O}$ (at room temperature) in carrier gas composed of $\mathrm{N}_{2}$ and $5 \% \mathrm{H}_{2}$ in $\mathrm{He}$ in a 2:1 ratio at a backing pressure of 10 bar. Ox is protonated by exothermic proton transfer from $\mathrm{H}_{3}{ }^{+}$and/or $\mathrm{H}^{+}\left(\mathrm{H}_{2} \mathrm{O}\right)_{n}$ clusters produced by chemical ionization, and clusters of $\mathrm{H}^{+} \mathrm{Ox}$ are then produced in the high-pressure regime of the supersonic expansion by three-body collisions. The desired parent clusters are mass-selected in the first quadrupole and irradiated in an adjacent octupole ion guide with a tunable IR laser pulse $\left(v_{\mathrm{IR}}, 10 \mathrm{~Hz}, 2-5 \mathrm{~mJ}\right.$, bandwidth $\sim 1 \mathrm{~cm}^{-1}$ ) emitted from an optical parametric oscillator pumped by a Q-switched nanosecond Nd:YAG laser. Calibration of $v_{\mathbb{R}}$ to better than $1 \mathrm{~cm}^{-1}$ is achieved by a wavemeter. Resonant vibrational excitation followed by intracluster vibrational energy redistribution leads to the evaporation of the most weakly bound neutral ligand, according to:

$$
\begin{aligned}
& \mathrm{H}^{+} \mathrm{Ox}-\mathrm{W}_{n}+v_{\mathbb{R}} \rightarrow \mathrm{H}^{+} \mathrm{Ox}-\mathrm{W}_{n-1}+\mathrm{W} \\
& \mathrm{H}^{+} \mathrm{Ox}-\mathrm{W}_{n}-\mathrm{N}_{2}+v_{\mathrm{R}} \rightarrow \mathrm{H}^{+} \mathrm{Ox}-\mathrm{W}_{n}+\mathrm{N}_{2}
\end{aligned}
$$

Subsequently, the fragment ions are mass-selected by the second quadrupole and monitored with a Daly ion detector as a function of $v_{\mathbb{R}}$ to derive the IRPD spectrum of $\mathrm{H}^{+} \mathrm{Ox}-\mathrm{W}_{n}\left(-\mathrm{N}_{2}\right)$. All IRPD spectra are linearly normalized for variations in the IR laser intensity measured with a pyroelectric detector. The contribution of metastable decay is subtracted from laser-induced dissociation by triggering the ion source at twice the laser repetition rate. The observed widths of the vibrational bands mainly arise from unresolved rotational structure, sequence hot bands involving inter- and intramolecular modes, and contributions from various structural isomers. Tagging with $\mathrm{N}_{2}$ produces colder clusters because their maximum internal energy is given by the binding energy of the weakliest bonded ligand. As a consequence of the lower effective temperature, the spectra of the $\mathrm{N}_{2}$-tagged clusters display higher spectral resolution.

\section{Computational Details}

Possible $\mathrm{H}^{+} \mathrm{Ox}-\mathrm{W}_{n}\left(-\mathrm{N}_{2}\right)$ isomers are optimized at the B3LYP-D3/aug-cc-pVTZ level of theory to analyze the IRPD spectra. ${ }^{63}$ This dispersion-corrected density functional reliably describes the electrostatic, induction, and dispersion forces of the investigated clusters. ${ }^{64-69}$ Neutral Ox and Ox-W are also computed to derive the 
impact of protonation on hydration on structure and intermolecular bonding. For energy optimization, the tight convergence criterion with ultrafine integration grid is used. In particular, the binding energy computed for the $\mathrm{W}_{2}$ dimer $\left(D_{0}=1103 \mathrm{~cm}^{-1}\right)$ is in excellent agreement with the measured value $\left(D_{0}=1105 \pm 10 \mathrm{~cm}^{-1}\right),{ }^{70}$ indicating that the $\mathrm{H}$-bond interactions in the hydration networks are modeled accurately by this computational approach. Fully relaxed potential energy surface calculations are performed during the search for stationary points, and their nature as minima or transition states is verified by harmonic frequency analysis. Harmonic intramolecular vibrational frequencies are subjected to a linear scaling factor of 0.9636 , derived from a comparison of computed $\mathrm{CH}$ and $\mathrm{OH}$ stretch frequencies of neutral $\mathrm{Ox}$ and $\mathrm{W}$, respectively, to their measured values. ${ }^{46,71}$ For convenient comparison to the experiment, harmonic linear IR absorption stick spectra are convoluted with a Gaussian line shape $\left(F W H M=10 \mathrm{~cm}^{-1}\right)$. All relative energies $\left(E_{\mathrm{e}}\right)$ and equilibrium dissociation energies $\left(D_{\mathrm{e}}\right)$ are corrected for harmonic zero-point vibrational energy to derive respective $E_{0}$ and $D_{0}$ values. Gibbs free energies are evaluated at $298 \mathrm{~K}\left(G_{0}\right)$. The total intermolecular dissociation energies are determined with respect to the molecular $\mathrm{H}^{+} \mathrm{Ox}$ and $\mathrm{W}$ monomer fragments (also for the proton-transferred isomers of $\mathrm{Ox}-\mathrm{H}^{+} \mathrm{W}_{4}$ ). The $D_{0}$ values reported for the tagged clusters correspond to binding energies of the $\mathrm{N}_{2}$ ligand. Previous experience with the employed computational level demonstrates that basis set superposition errors are smaller than $1 \%,{ }^{67,68}$ and thus they are not considered further here. The atomic charge distribution and second-order perturbation energies $\left(E^{(2)}\right)$ of the donor-acceptor orbital interaction involved in the $\mathrm{H}$-bonds are evaluated using the natural bond orbital (NBO) analysis. ${ }^{72,73}$ Further characterization of the $\mathrm{H}$-bonds is achieved in noncovalent interaction $(\mathrm{NCl})$ calculations by computing the reduced gradient of the electron density $\rho, s(\rho) \sim|\operatorname{grad}(\rho)| / \rho^{4 / 3}$, as a function of $\rho$ oriented by the sign of second eigenvalue $\lambda_{2}$ of the Hessian, $\rho^{*}=\rho \operatorname{sign}\left(\lambda_{2}\right) .{ }^{74,75}$ The relative strengths of various $\mathrm{H}$-bonds can be estimated by comparing their respective $\rho^{*}$ values.

\section{Results \& Discussion}

All IRPD spectra of $\mathrm{H}^{+} \mathrm{Ox}-\mathrm{W}_{n}\left(-\mathrm{N}_{2}\right)$ recorded between 2650 and $3820 \mathrm{~cm}^{-1}$ are compared in Figure 1. The positions and suggested vibrational and isomer assignments are listed in Table 1. The investigated spectral range covers the $\mathrm{OH}, \mathrm{NH}$, and $\mathrm{CH}$ stretch fundamentals $\left(v_{\mathrm{OH} / \mathrm{NH} / \mathrm{CH}}\right)$, which are sensitive to both the protonation site and the $\mathrm{H}$-bonded hydration network. Significantly, the appearance of the $\mathrm{H}^{+} \mathrm{Ox}-\mathrm{W}_{n}$ spectra changes drastically as a function of cluster size, thus providing detailed information about the evolution of the cluster growth. In addition, the IRPD spectra of the colder $\mathrm{N}_{2}$-tagged clusters display much narrower bands, which further facilitates the identification of the isomers observed for microhydrated $\mathrm{H}^{+} \mathrm{Ox}$. The bands A-C occur in the range of the free $\mathrm{OH}$ stretch modes of the $\mathrm{W}$ ligands $\left(3600-3750 \mathrm{~cm}^{-1}\right)$. Transitions $\mathrm{D}$ occur only for the $n \geq 2$ cluster and vary strongly with the cluster size $\left(3000-3400 \mathrm{~cm}^{-1}\right)$. Both their frequencies and band shapes suggest an assignment to bound $\mathrm{OH}$ stretch modes of the $W$ ligands. Transition $E$ at $3177 \pm 3 \mathrm{~cm}^{-1}$ is insensitive to $n$ and has been assigned to $\mathrm{CH}$ stretch modes in the IRPD spectra of $\mathrm{H}^{+} \mathrm{Ox}-\mathrm{L}_{n}$ with $\mathrm{L}=\mathrm{Ar}$ and $\mathrm{N}_{2}$, where this band occurs at a very similar position $\left(3168-3179 \mathrm{~cm}^{-1}\right) .{ }^{60}$ The intense transitions $\mathrm{F}$ occur below $3000 \mathrm{~cm}^{-1}$, as expected for bound $\mathrm{NH}$ stretch modes of cationic $\mathrm{NH} . . \mathrm{O} \mathrm{H}$-bonds. In the following, we discuss the evolution of the observed IRPD spectra as a function of cluster size with the aid of the DFT calculations and derive more precise vibrational and isomer assignments.

\subsection{Ox, $\mathrm{H}^{+} \mathrm{Ox}$, and $\mathrm{W}$}


The geometric and vibrational properties of neutral Ox and $\mathrm{H}^{+} \mathrm{Ox}$ calculated at the B3LYP-D3/aug-cc-pVTZ level are discussed in detail in our previous report. ${ }^{60}$ The structure and vibrations computed for Ox agree satisfactorily with available experimental data. ${ }^{46,52}$ The same is true for the corresponding predicted and measured properties of bare $\mathrm{W}\left(r_{\mathrm{OH}}=0.9617\right.$ vs. $0.9578 \AA, v_{1 / 3}=3656 / 3755$ vs. $\left.\left.3657 / 3756 \mathrm{~cm}^{-1}\right)\right)^{71,76}$ Protonation of $\mathrm{Ox}$ at the $\mathrm{N}$ atom is energetically strongly favored over protonation at the $\mathrm{O}$ and $\mathrm{C}$ atoms of the heterocyclic ring (by more than $120 \mathrm{~kJ} / \mathrm{mol}$ ), and indeed our previous analysis of the IRPD spectra of $\mathrm{H}^{+} \mathrm{Ox}-\mathrm{L}_{n}$ with $\mathrm{L}=\mathrm{Ar}$ and $\mathrm{N}_{2}$ confirms exclusive $\mathrm{N}$-protonation under the present experimental conditions. In addition, the experimental proton affinity recommended for $\mathrm{Ox}(\mathrm{PA}=876.4 \mathrm{~kJ} / \mathrm{mol})^{59}$ is in excellent agreement with our value computed for the $\mathrm{N}$-protomer $(876.7 \mathrm{~kJ} / \mathrm{mol}) .{ }^{60}$ Hence, we only consider this protomer further in the present study on $\mathrm{H}^{+} \mathrm{Ox}-\mathrm{W}_{n}$. From the IRPD spectra of the $\pi$-bound $\mathrm{H}^{+} \mathrm{Ox}-\mathrm{Ar} / \mathrm{N}_{2}$ dimers, the free $\mathrm{NH}$ stretch frequency of bare $\mathrm{H}^{+} \mathrm{Ox}$ is estimated as $v_{\mathrm{NH}}=3444 \pm 3 \mathrm{~cm}^{-1}, 60$ in excellent agreement with the predicted value $\left(3446 \mathrm{~cm}^{-1}\right)$. In conclusion, the employed theoretical level describes the relevant properties of the considered monomers to high accuracy.

\section{2 $\mathrm{H}^{+} \mathrm{Ox}-\mathrm{W}$ and $\mathrm{H}^{+} \mathrm{Ox}-\mathrm{W}-\mathrm{N}_{2}$}

In analogy to the $\mathrm{H}^{+} \mathrm{Ox}-\mathrm{Ar} / \mathrm{N}_{2}$ dimers, ${ }^{60}$ we consider particularly the $\mathrm{H}$-bound and $\pi$-bound $\mathrm{H}^{+} \mathrm{Ox}-\mathrm{W}$ structures (Figure 2). Because the intermolecular attraction in $\mathrm{H}^{+} \mathrm{Ox}-\mathrm{W}$ is dominated by electrostatic chargedipole forces, all minima on the potential energy surface have the typical cation-dipole configuration with the $\mathrm{O}$ atom of $\mathrm{W}$ pointing toward the positive charge of $\mathrm{H}^{+} \mathrm{Ox}$. The global $\mathrm{H}$-bonded $\mathrm{H}^{+} \mathrm{Ox}-\mathrm{W}(\mathrm{H})$ minimum, with a nearly linear $\mathrm{NH} \ldots \mathrm{O}$ ionic $\mathrm{H}$-bond $\left(R_{\mathrm{NH} \ldots \mathrm{O}}=1.659 \AA\right)$ and the plane of $\mathrm{W}$ perpendicular to the plane of $\mathrm{H}^{+} \mathrm{Ox}$, is nearly twice more stable than $\mathrm{H}^{+} \mathrm{Ox}-\mathrm{W}(\pi), D_{0}=6094$ vs. $3334 \mathrm{~cm}^{-1}$. This ionic $\mathrm{H}$-bond is substantially stronger than the $\mathrm{OH} \ldots \mathrm{N} \mathrm{H}$-bond of the neutral Ox-W dimer $\left(D_{0}=1697 \mathrm{~cm}^{-1}, R_{\mathrm{OH}} . . \mathrm{N}=1.951 \AA\right)$, in which W is $\mathrm{H}$-bonded as proton donor to the in-plane lone pair of $\mathrm{N}$ in $\mathrm{Ox}$ (Figure $\mathrm{S} 1$ in the supporting information). ${ }^{49,60}$ The strong $\mathrm{H}$-bond in $\mathrm{H}^{+} \mathrm{Ox}-\mathrm{W}(\mathrm{H})$ significantly perturbs the $\mathrm{NH}$ group, resulting in a massive red shift and pronounced enhancement in the IR oscillator strength of the bound $\mathrm{NH}$ stretch mode $\left(v_{\mathrm{NH}}{ }^{\mathrm{b}}\right)$ when compared to bare $\mathrm{H}^{+} \mathrm{Ox}\left(\Delta r_{\mathrm{NH}}=32.7 \mathrm{~mA}, \Delta v_{\mathrm{NH}}{ }^{\mathrm{b}}=-546 \mathrm{~cm}^{-1}, \Delta /_{\mathrm{NH}}=1638 \mathrm{~km} / \mathrm{mol}\right)$. The substantial PA of $\mathrm{W}(691 \mathrm{~kJ} / \mathrm{mol})$ facilitates $\mathrm{H}$-bonding through a significant charge transfer from $\mathrm{H}^{+} \mathrm{O}$ to $\mathrm{W}(\Delta q=0.06$ e, Figure $\mathrm{S} 2$ in the supporting information), ${ }^{59}$ which leads to slight red shifts and concomitant enhancement of IR intensities of the $v_{1 / 3}$ modes compared to bare $\mathrm{W}\left(\Delta v_{1 / 3}=-16 /-29 \mathrm{~cm}^{-1}, \Delta l_{1 / 3}=51 / 88 \mathrm{~km} / \mathrm{mol}\right)$. The barrier for internal rotation of $W$ of $V_{b}=281 \mathrm{~cm}^{-1}$ in $\mathrm{H}^{+} \mathrm{Ox}-\mathrm{W}(\mathrm{H})$ at the planar transition state is substantial (Figure $\mathrm{S} 3$ in the supporting information). As expected, the $\pi$-bound $W$ ligand in $\mathrm{H}^{+} \mathrm{Ox}-\mathrm{W}(\pi)$ has no significant influence on the $\mathrm{NH}$ group, and the associated parameters are comparable to those of bare $\mathrm{H}^{+} \mathrm{Ox}\left(\Delta r_{\mathrm{NH}}=-1.8 \mathrm{~m} \AA, \Delta v_{\mathrm{NH}}=19 \mathrm{~cm}^{-1}, \Delta /_{\mathrm{NH}}=-\right.$ $19 \mathrm{~km} / \mathrm{mol})$. Similar to $\mathrm{H}^{+} \mathrm{Ox}-\mathrm{W}(\pi)$, the $\mathrm{H}^{+} \mathrm{Ox}-\mathrm{W}(\mathrm{C} 5)$ structure with a $\mathrm{CH} \ldots \mathrm{O}$ ionic $\mathrm{H}$-bond is a high-energy local minimum $\left(D_{0}=3239 \mathrm{~cm}^{-1}\right)$, because the $\mathrm{CH}$ bonds are much less acidic than the $\mathrm{NH}$ group (Figure $\mathrm{S} 4$ in the supporting information). Attempts to optimize other structures with a $\mathrm{CH} \ldots \mathrm{O} \mathrm{H}$-bond failed ( $\mathrm{C} 2$ and $\mathrm{C} 4)$, probably because of very low barriers for $\mathrm{W}$ migration toward the nearby acidic $\mathrm{NH}$ group. Again, for the $\mathrm{CH}-$ bonded isomer, the perturbation of the $\mathrm{NH}$ group is minor. 
To elucidate the effects of $\mathrm{N}_{2}$ tagging on the $\mathrm{H}^{+} \mathrm{Ox}-\mathrm{W}$ dimer, we merely consider the by far most stable $\mathrm{H}^{+} \mathrm{Ox}-\mathrm{W}(\mathrm{H})$ isomer (Figure 2), because it is the only one observed experimentally (vide infra). The $\mathrm{N}_{2}$ ligand is either $\mathrm{H}$-bonded to $\mathrm{W}\left(D_{0}=937 \mathrm{~cm}^{-1}\right)$ or forms a $\pi$-bond with a smaller binding affinity $\left(D_{0}=766 \mathrm{~cm}^{-1}\right)$. Although binding of $\mathrm{N}_{2}$ to the $\mathrm{CH}$ groups is comparable in strength to $\pi$-bonding, this binding motif is not observed experimentally in the IRPD spectra of $\mathrm{H}^{+} \mathrm{Ox}-\left(\mathrm{N}_{2}\right)_{n}{ }^{60}$ The cooperativity arising from the additional $\mathrm{H}$ bonded $\mathrm{N}_{2}$ ligand in $\mathrm{H}^{+} \mathrm{Ox}-\mathrm{W}(\mathrm{H})-\mathrm{N}_{2}(\mathrm{H})$ increases the $\mathrm{N}-\mathrm{H}$ bond length, leading to further lowering of $v_{\mathrm{NH}}{ }^{b}$ compared to $\mathrm{H}^{+} \mathrm{Ox}-\mathrm{W}(\mathrm{H})$, with $\Delta r_{\mathrm{NH}}=6.1 \mathrm{~m} \AA$ and $v_{\mathrm{NH}}{ }^{\mathrm{b}}=2785$ vs. $2883 \mathrm{~cm}^{-1}$. In addition, the $\mathrm{OH} \ldots \mathrm{N}_{2} \mathrm{H}$-bond elongates the $\mathrm{O}-\mathrm{H}$ donor bond with a concomitant red shift of the coupled $v_{1 / 3}$ modes $\left(\Delta v_{1 / 3}=-66 /-22 \mathrm{~cm}^{-1}\right)$. On the contrary, the $\pi$-bound $\mathrm{N}_{2}$ ligand in $\mathrm{H}^{+} \mathrm{Ox}-\mathrm{W}(\mathrm{H})-\mathrm{N}_{2}(\pi)$ hardly affects the $\mathrm{NH}$ and $\mathrm{OH}$ groups. The slight increase in $v_{\mathrm{NH}}{ }^{\mathrm{b}}\left(+26 \mathrm{~cm}^{-1}\right)$ is rationalized by noncooperative effects of interior ion solvation resulting from $\mathrm{N}_{2}$ attachment at the $\pi$-site, which however barely influences the free $v_{1 / 3}$ modes $\left(+1 /+1 \mathrm{~cm}^{-1}\right)$.

The IRPD spectra of $\mathrm{H}^{+} \mathrm{Ox}-\mathrm{W}$ and $\mathrm{H}^{+} \mathrm{Ox}-\mathrm{W}-\mathrm{N}_{2}$ are compared in Figure 3 to the relevant computed spectra. The IRPD spectrum of $\mathrm{H}^{+} \mathrm{Ox}-\mathrm{W}$ exhibits an intense broad feature between 2650 and $3220 \mathrm{~cm}^{-1}(\mathrm{~F} 1-\mathrm{F} 3, \mathrm{E})$ along with two relatively weak and narrower transitions at $3720(\mathrm{~A})$ and $3625(\mathrm{~B}) \mathrm{cm}^{-1}$. Significantly, this spectrum lacks any signal of a $v_{N H}{ }^{\dagger}$ mode of $\mathrm{H}^{+} \mathrm{Ox}$ near $3450 \mathrm{~cm}^{-1}$. This observation implies that the $\mathrm{NH}$ group in $\mathrm{H}^{+} \mathrm{Ox}-\mathrm{W}$ is engaged in $\mathrm{H}$-bonding to $\mathrm{W}$, which immediately excludes any $\pi$-bonded or $\mathrm{CH}$-bonded isomers (Figure 3, Figure S4 in the supporting information), consistent with the thermochemical predictions. The two bands $B$ and $A$ are then readily assigned to the free $v_{1 / 3}$ modes of the $\mathrm{H}^{+} \mathrm{Ox}-\mathrm{W}(\mathrm{H})$ global minimum computed as $3642 / 3728 \mathrm{~cm}^{-1}$. The experimental red shifts of $\Delta v_{1 / 3}=-31 /-36 \mathrm{~cm}^{-1}$ are typical for cation-W bonding and consistent with the predictions $\left(-16 /-29 \mathrm{~cm}^{-1}\right)$. Clearly, the dissociation energy computed for this isomer $\left(D_{0}=6094 \mathrm{~cm}^{-1}\right)$ is substantially larger than the absorbed photon energy $\left(v_{\mathbb{R}}\right)$, indicating that only internally hot clusters with $E_{\text {int }}>3500 \mathrm{~cm}^{-1}$ are detected under the employed single-photon absorption conditions. This view is consistent with the large widths of the observed bands. The broad feature comprising bands F1-F3 and other unresolved peaks in the $2700-3200 \mathrm{~cm}^{-1}$ range are attributed to the $v_{\mathrm{NH}}{ }^{\mathrm{b}}$ mode (predicted at $2883 \mathrm{~cm}^{-1}$ ), which interacts with other combination bands and overtones (e.g., the overtone of the $\mathrm{NH}$ bend $\left(2 \beta_{\mathrm{NH}}\right)$ predicted at $\left.2932 \mathrm{~cm}^{-1}\right)$ via strong anharmonic coupling. Such a spectral feature is very typical for strong cationic $\mathrm{NH}$... O H-bonds with $\mathrm{W}$ as proton acceptor, and has been observed for a variety of monohydrated aromatic clusters. ${ }^{69,77,78}$ The transition with highest intensity (F3) probably carries the largest $\mathrm{NH}$ stretch character. Transition $\mathrm{E}$ at $3179 \mathrm{~cm}^{-1}$ is mostly assigned to two close-lying aromatic $v_{\mathrm{CH}}$ modes, which are detected at $\sim 3175 \mathrm{~cm}^{-1}$ for $\mathrm{H}^{+} \mathrm{Ox}-\mathrm{Ar} / \mathrm{N}_{2}{ }^{60}$ The relatively weak band $\mathrm{X}$ around $3230 \mathrm{~cm}^{-1}$ is tentatively assigned to the $\mathrm{OH}$ bending overtone of $\mathrm{W}$ predicted near $3226 \mathrm{~cm}^{-1}$ from the harmonic analysis (using 0.98 as scaling factor).

The assignment of the $\mathrm{H}^{+} \mathrm{Ox}-\mathrm{W}$ spectrum to the hot population of the single $\mathrm{H}^{+} \mathrm{Ox}-\mathrm{W}(\mathrm{H})$ isomer is supported by the IRPD spectrum of cold $\mathrm{H}^{+} \mathrm{Ox}-\mathrm{W}-\mathrm{N}_{2}$ clusters in Figure 3. Tagging with $\mathrm{N}_{2}$ drastically reduces the maximum internal energy to below $1000 \mathrm{~cm}^{-1}$ and facilitates single-photon IRPD from the ground vibrational state of the clusters. As a result, the widths of the transitions are narrower and the appearance of the spectrum in the $v_{\mathrm{NH}}{ }^{\mathrm{b}}$ range is cleaner. The $\mathrm{OH}$ stretch bands $\mathrm{B}$ and $\mathrm{A}$ of the tagged cluster at 3610 and $3711 \mathrm{~cm}^{-1}$ are red shifted from those of the bare dimer $\left(\Delta v_{1 / 3}=-15 /-9 \mathrm{~cm}^{-1}\right)$, suggesting that the $\mathrm{N}_{2}$ ligand forms a $\mathrm{H}$-bond to the $\mathrm{W}$ ligand, $\mathrm{H}^{+} \mathrm{Ox}-\mathrm{W}(\mathrm{H})-\mathrm{N}_{2}(\mathrm{H})$, so that we can exclude isomers with $\mathrm{CH}$-bonded or $\pi$ - 
bonded $\mathrm{N}_{2}$ ligands. The harmonic calculations overestimate these shifts $\left(\Delta v_{1 / 3}=-66 /-22 \mathrm{~cm}^{-1}\right)$, partly because of the high temperature of the untagged monohydrate. The width of the intense $\mathrm{H}$-bonded transition $\mathrm{F}$ is remarkably reduced upon cooling with the $\mathrm{N}_{2}$ tag, and the extracted $v_{\mathrm{NH}}{ }^{\mathrm{b}}$ fundamental of $2970 \mathrm{~cm}^{-1}$ is to be compared to the computed value of $2785 \mathrm{~cm}^{-1}$. This discrepancy may be attributed to the highly anharmonic nature of this $\mathrm{H}$-bonded oscillator. Furthermore, the measured intensity ratio of the $v_{\mathrm{CH}}$ band $\left(\mathrm{E}\right.$ at $\left.3178 \mathrm{~cm}^{-1}\right)$ relative to the $v_{\mathrm{NH}}{ }^{\mathrm{b}}$ band in the tagged spectrum agrees well with the predictions, confirming that anharmonic couplings and effects of hot bands are drastically reduced for the cold $\mathrm{N}_{2}$-tagged ions. This spectral behavior upon tagging is again typical for strong cationic $\mathrm{NH} \ldots \mathrm{O} \mathrm{H}$-bonds of aromatic cations with $\mathrm{W}^{69,77,78}$

\section{3 $\mathrm{H}^{+} \mathrm{Ox}-\mathrm{W}_{2}$ and $\mathrm{H}^{+} \mathrm{Ox}-\mathrm{W}_{2}-\mathrm{N}_{2}$}

In the most stable $\mathrm{H}^{+} \mathrm{Ox}-\mathrm{W}_{2}(\mathrm{H})$ structure, a $\mathrm{H}$-bonded $\mathrm{W}_{2}$ dimer forms an $\mathrm{NH} \ldots \mathrm{O} \mathrm{H}$-bond to $\mathrm{H}^{+} \mathrm{Ox}$ with a total interaction energy of $D_{0}=10278 \mathrm{~cm}^{-1}$ (Figure 4). The formation of such a $\mathrm{H}$-bonded network is strongly cooperative in nature. For example, $D_{0}$ of $\mathrm{H}^{+} \mathrm{Ox}-\mathrm{W}_{2}$ is $43 \%$ larger than the sum of the binding energies of $\mathrm{W}_{2}$ and $\mathrm{H}^{+} \mathrm{Ox}-\mathrm{W}\left(D_{0}=1103+6094=7197 \mathrm{~cm}^{-1}\right)$. Similarly, the intermolecular $\mathrm{NH} \ldots \mathrm{O}$ and $\mathrm{OH} \ldots \mathrm{O} \mathrm{H}$-bonds of the two units contract drastically $\left(R_{\mathrm{NH} \ldots \mathrm{O}}=1.555\right.$ vs. $1.659 \AA, R_{\mathrm{OH} \ldots \mathrm{O}}=1.712$ vs. $\left.1.947 \AA\right)$. This large cooperatively can mostly be traced back to the substantially increased $P A$ of $W_{2}$ as compared to $W$ (PA=808 vs. 691 $\mathrm{kJ} / \mathrm{mol})^{59,79}$ and the strong polarization effects induced by the positive charge of the excess proton. As a result, the N-H bond gets further elongated upon attachment of the second $\mathrm{W}\left(\Delta r_{\mathrm{NH}}=21 \mathrm{~m} \AA\right)$ and the total red shift and IR oscillator strength of the $v_{\mathrm{NH}}{ }^{\mathrm{b}}$ mode become more pronounced $\left(\Delta v_{\mathrm{NH}}=-892\right.$ vs. $-563 \mathrm{~cm}^{-1}$, $\left.I_{\mathrm{NH}}=2853 \mathrm{vs.} 1840 \mathrm{~km} / \mathrm{mol}\right)$. The increased distance of the terminal $W$ from the positive charge results in a slight blue shift in $v_{1 / 3}$ compared to the dimer $\left(\Delta v_{1 / 3}=+9 /+11 \mathrm{~cm}^{-1}\right)$. The new free OH stretch mode $\left(v_{\mathrm{f}}\right)$ of the first $W$ ligand is predicted between the two $v_{1 / 3}$ modes at $3712 \mathrm{~cm}^{-1}$, whereas its $\mathrm{H}$-bonded $\mathrm{OH}$ stretch mode $\left(v_{\mathrm{OH}}{ }^{\mathrm{b}}\right)$ is strongly red shifted down to $3267 \mathrm{~cm}^{-1}$, consistent with its longer bond length $\left(\Delta r_{\mathrm{OH}}=23.5 \mathrm{~m} \AA\right)$. This red shift is much larger than for bare $W_{2}\left(v_{\mathrm{OH}}{ }^{b}=3601 \mathrm{~cm}^{-1}\right)^{80-82}$ because of the strong cooperativity effect on the $\mathrm{W}-\mathrm{W} \mathrm{H}$-bond introduced by the presence of the $\mathrm{H}^{+} \mathrm{Ox}$ cation. Other isomers of $\mathrm{H}^{+} \mathrm{Ox}-\mathrm{W}_{2}$ with two individual $\mathrm{W}$ ligands attached to $\mathrm{H}^{+} \mathrm{Ox}$ are less favorable, because binding sites other than the $\mathrm{NH}$ group (e.g., $\pi$ or $\mathrm{CH}$ ) are less favorable and interior ion solvation is noncooperative in nature. This is illustrated for the example of the $\mathrm{H}^{+} \mathrm{Ox}-\mathrm{W}_{2}(\mathrm{I})$ isomer shown in Figure 4, in which two $\mathrm{W}$ ligands are separately $\mathrm{H}$-bonded to the $\mathrm{NH}$ and $\mathrm{C} 5 \mathrm{H}$ groups $\left(D_{0}=8955 \mathrm{~cm}^{-1}\right)$. The noncooperativity in binding energy amounts to $8955 /(3239+6094)=0.96$ or $4 \%$ for this isomer. Apart from this thermochemical argument, the IRPD spectrum of $\mathrm{H}^{+} \mathrm{Ox}-\mathrm{W}_{2}$ in Figure 1 shows a drastic change in the $v_{\mathrm{NH}}{ }^{\mathrm{b}}$ range compared to that of $\mathrm{H}^{+} \mathrm{Ox}-\mathrm{W}$, indicating that the second $\mathrm{W}$ ligand is strongly perturbing the $\mathrm{NH}$ group, which can only be for the $\mathrm{H}^{+} \mathrm{Ox}-\mathrm{W}_{2}(\mathrm{H})$ structure with a $\mathrm{H}$-bonded $\mathrm{W}_{2}$ unit.

We consider the three main binding motifs for attachment of $\mathrm{N}_{2}$ to $\mathrm{H}^{+} \mathrm{Ox}-\mathrm{W}_{2}(\mathrm{H})$ shown in Figure 4, namely $\mathrm{H}$-bonding to a free $\mathrm{OH}$ group of the $\mathrm{W}_{2}$ unit and $\pi$-bonding to $\mathrm{H}^{+} \mathrm{Ox}$. $\mathrm{N}_{2}$-bonding to $\mathrm{CH}$ groups is energetically less favorable and indeed not observed for $\mathrm{H}^{+} \mathrm{Ox}-\left(\mathrm{N}_{2}\right)_{n}{ }^{60}$ In the most stable $\mathrm{H}^{+} \mathrm{Ox}-\mathrm{W}_{2}(\mathrm{H})-\mathrm{N}_{2}(\mathrm{H} 1)$ isomer $\left(D_{0}=789 \mathrm{~cm}^{-1}\right), \mathrm{N}_{2}$ forms a $\mathrm{H}$-bond to the remaining free $\mathrm{OH}$ group of the first $\mathrm{W}$ ligand, resulting in a slight elongation of the O-H bond with a concomitant decrease in $v_{\mathrm{f}}\left(\Delta r_{\mathrm{OH}}=3 \mathrm{~m} \AA, \Delta v_{\mathrm{OH}}=-69 \mathrm{~cm}^{-1}\right)$. In the less stable $\mathrm{H}^{+} \mathrm{Ox}-\mathrm{W}_{2}(\mathrm{H})-\mathrm{N}_{2}(\mathrm{H} 2)$ isomer, the $\mathrm{N}_{2}$ ligand binds to the terminal $W$ ligand. It is thus further away from 
the positive charge leading to a lower binding energy $\left(D_{0}=694 \mathrm{~cm}^{-1}\right)$ and longer $\mathrm{OH} \ldots \mathrm{N}_{2}$ bond. As a result, the red shifts of $v_{1 / 3}$ from free $W$ are smaller $\left(\Delta v_{1 / 3}=-39 /-19 \mathrm{~cm}^{-1}\right)$ than for the analogous $\mathrm{H}^{+} \mathrm{Ox}-\mathrm{W}(\mathrm{H})-\mathrm{N}_{2}(\mathrm{H})$ structure. In both isomers $\mathrm{H}^{+} \mathrm{Ox}-\mathrm{W}_{2}(\mathrm{H})-\mathrm{N}_{2}(\mathrm{H} 1 / 2)$, the additional $\mathrm{H}$-bonded $\mathrm{N}_{2}$ ligand slightly strengthens (and contracts) the $\mathrm{NH} \ldots \mathrm{O} \mathrm{H}$-bond between $\mathrm{H}^{+} \mathrm{Ox}$ and $\mathrm{W}_{2}$, because of the cooperativity of the $\mathrm{H}$-bonded network and the higher PA of $\mathrm{W}_{2}-\mathrm{N}_{2}$ compared to $\mathrm{W}_{2}$. This in turn is visible in a modest elongation of the N-H bond and a small red shift in $v_{N H}{ }^{b}$. In contrast, the additional $\pi$-bound $\mathrm{N}_{2}$ ligand in $\mathrm{H}^{+} \mathrm{Ox}-\mathrm{W}_{2}(\mathrm{H})-\mathrm{N}_{2}(\pi)$ is mostly stabilized by charge-quadrupole and charge-induced dipole interactions, resulting in a $D_{0}$ value $\left(695 \mathrm{~cm}^{-1}\right)$ similar to that of $\mathrm{H}^{+} \mathrm{Ox}-\mathrm{W}_{2}(\mathrm{H})-\mathrm{N}_{2}(\mathrm{H} 2)$. As expected, $\pi$-tagging has no significant effect on the IR spectrum of $\mathrm{H}^{+} \mathrm{Ox}-\mathrm{W}_{2}(\mathrm{H})$ in the $\mathrm{XH}$ stretch range.

The IRPD spectra recorded for $\mathrm{H}^{+} \mathrm{Ox}-\mathrm{W}_{2}$ and $\mathrm{H}^{+} \mathrm{Ox}-\mathrm{W}_{2}-\mathrm{N}_{2}$ are compared in Figure 5 to the relevant computed spectra. The spectrum of bare $\mathrm{H}^{+} \mathrm{Ox}-\mathrm{W}_{2}$ is drastically different from that of the $n=1$ cluster (Figure 1). For example, it no longer exhibits the broad transitions F1-F3. Instead, we observe a rising signal toward the red end of the scan $\left(2650 \mathrm{~cm}^{-1}\right)$, which we tentatively assign to the blue tail of $v_{\mathrm{NH}}{ }^{\mathrm{b}}$, yielding an upper limit of the $v_{\mathrm{NH}}{ }^{\mathrm{b}}$ fundamental predicted at $2554 \mathrm{~cm}^{-1}$. This drastic spectral change in the $v_{\mathrm{NH}}{ }^{\mathrm{b}}$ range confirms that the second $W$ ligand binds to the first one. The new feature $C$ at $3705 \mathrm{~cm}^{-1}$ lies between the transitions $B$ $\left(3649 \mathrm{~cm}^{-1}\right)$ and $A\left(3745 \mathrm{~cm}^{-1}\right)$ and agrees well with the predicted $v_{\mathrm{f}}$ mode $\left(3712 \mathrm{~cm}^{-1}\right)$ of the first W ligand next to the positively charged $\mathrm{H}^{+} \mathrm{Ox}$. The other two transitions $\mathrm{B}$ and $\mathrm{A}$ in the free $\mathrm{OH}$ stretch range are readily assigned to $v_{1 / 3}$ of the terminal $W$ ligand predicted at 3651 and $3739 \mathrm{~cm}^{-1}$, which are indeed blueshifted from the corresponding transitions of $\mathrm{H}^{+} \mathrm{Ox}-\mathrm{W}$, because of the larger separation of the terminal $\mathrm{W}$ from the center of the positive charge. The other new and rather intense feature $D$ at $3338 \mathrm{~cm}^{-1}$ is safely attributed to the $\mathrm{H}$-bonded $\mathrm{OH}$ stretch mode of the $\mathrm{W}_{2}$ unit in $\mathrm{H}^{+} \mathrm{Ox}-\mathrm{W}_{2}(\mathrm{H})$ predicted at $v_{\mathrm{OH}}{ }^{\mathrm{b}}=3267 \mathrm{~cm}^{-1}$. Again, the predicted harmonic frequency shift somewhat overestimates the measured shift of the fundamental frequency upon $\mathrm{H}$-bonding, due to the strongly anharmonic nature of the proton-donor stretch mode. As predicted, the $\mathrm{H}$-bonded $\mathrm{OH}$ stretch frequency in $\mathrm{H}^{+} \mathrm{Ox}-\mathrm{W}_{2}$ is much lower than in isolated $\mathrm{W}_{2}(3338$ vs. $3601 \mathrm{~cm}^{-1}$ ) due to the large cooperativity. ${ }^{80,81}$ Band $\mathrm{E}$ at $3179 \mathrm{~cm}^{-1}$ in the $\mathrm{H}^{+} \mathrm{Ox}-\mathrm{W}_{2}$ spectrum is unshifted from the $n=1$ spectrum, which confirms its assignment to the aromatic $v_{\mathrm{CH}}$ modes. Closer inspection reveals some signal between bands $E$ and $D$ above the background (band $X, 3247 \mathrm{~cm}^{-1}$ ), which we tentatively assign to the bending overtones of the $\mathrm{W}$ ligands, $2 \beta_{\mathrm{OH}}$, predicted at 3261 and $3209 \mathrm{~cm}^{-1}$. In conclusion, all major features of the $\mathrm{H}^{+} \mathrm{Ox}-\mathrm{W}_{2}$ spectrum can reliably be attributed to the most stable isomer, which features a $\mathrm{H}$ bonded solvent network. This result is qualitatively different from the $\mathrm{H}^{+} \mathrm{Ox}-\mathrm{L}_{n}$ structures with $\mathrm{L}=\mathrm{Ar}$ and $\mathrm{N}_{2}$, in which the aprotic ligands bind individually to the central $\mathrm{H}^{+} \mathrm{Ox}$ cation at various binding sites (interior ion solvation).

Similar to the $n=1$ case, the IRPD spectrum of tagged $\mathrm{H}^{+} \mathrm{Ox}-\mathrm{W}_{2}-\mathrm{N}_{2}$ in Figure 5 features bands with narrower widths due to the reduced internal energy. In general, it confirms the spectral features and assignments of the bare cluster. The most striking difference is the relative intensity of band $\mathrm{C} 1$ at $3707 \mathrm{~cm}^{-1}$ assigned to $v_{f}$ of the first $\mathrm{W}$ ligand, which is strongly reduced in intensity by $\mathrm{N}_{2}$ tagging compared to bands $\mathrm{B}$ and $\mathrm{A}$ but keeps its position compared to the $n=1$ spectrum $\left(3705 \mathrm{~cm}^{-1}\right)$. Such an effect is expected for the predominant presence of the most stable $\mathrm{H}^{+} \mathrm{Ox}-\mathrm{W}_{2}(\mathrm{H})-\mathrm{N}_{2}(\mathrm{H} 1)$ isomer, in which this free $\mathrm{OH}$ group is solvated by $\mathrm{N}_{2}$, which shifts this mode to the red. Following this scenario, bands $D, C 2$, and $A$ at 3312,3667 , and 
$3742 \mathrm{~cm}^{-1}$ are assigned to $v_{\mathrm{OH}}{ }^{\mathrm{b}}, v_{\mathrm{f}}$, and $v_{3}$ modes of $\mathrm{H}^{+} \mathrm{Ox}-\mathrm{W}_{2}(\mathrm{H})-\mathrm{N}_{2}(\mathrm{H} 1)$. Its $\mathrm{N}_{2}$-bonded $v_{\mathrm{f}}$ transition overlaps with band $\mathrm{C} 2$. The remaining weak band $\mathrm{C} 1$ must be ascribed to the $v_{\mathrm{f}}$ mode of the much less abundant local minima, $\mathrm{H}^{+} \mathrm{Ox}-\mathrm{W}_{2}(\mathrm{H})-\mathrm{N}_{2}(\mathrm{H} 2)$ and/or $\mathrm{H}^{+} \mathrm{Ox}-\mathrm{W}_{2}(\mathrm{H})-\mathrm{N}_{2}(\pi)$. Like for the spectrum of the untagged cluster, the transitions $E$ and $X$ in the $\mathrm{H}^{+} \mathrm{Ox}-\mathrm{W}_{2}-\mathrm{N}_{2}$ spectrum are attributed to the $v_{\mathrm{CH}}$ and $2 \beta_{\mathrm{OH}}$ vibrations. Careful analysis of the high-frequency range reveals that band $\mathrm{C} 2$ at $3667 \mathrm{~cm}^{-1}$ exhibits a shoulder at $3657 \mathrm{~cm}^{-1}$ (B), which is attributed to $v_{1}$ of $\mathrm{H}^{+} \mathrm{Ox}-\mathrm{W}_{2}(\mathrm{H})-\mathrm{N}_{2}(\mathrm{H} 1 / \pi)$.

\section{$4.4 \mathrm{H}^{+} \mathrm{Ox}-\mathrm{W}_{3}$}

We consider the two most stable $\mathrm{H}^{+} \mathrm{Ox}-\mathrm{W}_{3}$ geometries that are obtained by adding a third $\mathrm{W}$ ligand to either the first or the second $W$ ligand of $\mathrm{H}^{+} \mathrm{Ox}-\mathrm{W}_{2}(\mathrm{H})$. The branched $\mathrm{H}^{+} \mathrm{Ox}-\mathrm{W}_{3}(\mathrm{~b})$ isomer with $C_{\mathrm{s}}$ symmetry is calculated to be slightly more stable than the chain-type $\mathrm{H}^{+} \mathrm{Ox}-\mathrm{W}_{3}(\mathrm{l})$ isomer with a linear $\mathrm{H}$-bonded $\mathrm{W}_{3}$ chain $\left(D_{0}=13908 \mathrm{vs} .13582 \mathrm{~cm}^{-1}\right)$. The cooperativity is slightly stronger for the branched isomer $(67.4 \mathrm{vs} .63 .6 \%)$ because of hydration closer to the positive charge of $\mathrm{H}^{+} \mathrm{Ox}$. The additional $\mathrm{W}$ in $\mathrm{H}^{+} \mathrm{Ox}-\mathrm{W}_{3}(\mathrm{~b})$ further strengthens the $\mathrm{NH} \ldots \mathrm{OH}$-bond as compared to the $n=2$ case $\left(\Delta R_{\mathrm{NH} \ldots \mathrm{O}}=-101 \mathrm{~m} \AA\right)$, consistent with the larger PA of $W_{3}$ compared to $W_{2}$ (862 vs. $808 \mathrm{~kJ} / \mathrm{mol}$ ). ${ }^{79,83}$ As a result, the $\mathrm{N}-\mathrm{H}$ bond elongates from 1.066 to 1.099 $\AA$, and the total red shift of $v_{\mathrm{NH}}{ }^{\mathrm{b}}$ increases from -892 to $-1339 \mathrm{~cm}^{-1}$. The free $v_{1 / 3}$ modes of the terminal W ligands are calculated at 3654 and $3744 \mathrm{~cm}^{-1}$, while the $\mathrm{H}$-bonded antisymmetric and symmetric $v_{\mathrm{OH}}{ }^{\mathrm{b}}$ frequencies of the first $W$ are strongly reduced to 3384 and $3349 \mathrm{~cm}^{-1}$, respectively.

The linear $\mathrm{W}_{3}$ chain in the $\mathrm{H}^{+} \mathrm{Ox}-\mathrm{W}_{3}(\mathrm{l})$ isomer has a less pronounced effect on the $\mathrm{NH}$ group as compared to the branched isomer, with a weaker $\mathrm{NH}$... O H-bond $\left(R_{\mathrm{NH} \ldots \mathrm{O}}=1.507\right.$ vs. $\left.1.454 \AA\right)$ and thus a smaller $\mathrm{N}-\mathrm{H}$ bond elongation and less pronounced total $v_{\mathrm{NH}}{ }^{\mathrm{b}}$ red shift $\left(r_{\mathrm{NH}}=1.0799 \AA, \Delta v_{\mathrm{NH}}{ }^{\mathrm{b}}=-1092\right)$. Its $v_{1 / 3}$ modes of the terminal $\mathrm{W}$ are comparable to those of the branched isomer. However, the linear $\mathrm{W}_{3}$ network features characteristics free $v_{\mathrm{f}}$ modes of the two dangling $\mathrm{OH}$ groups calculated at 3717 and $3715 \mathrm{~cm}^{-1}$. The $v_{\mathrm{OH}}{ }^{\mathrm{b}}$ mode of the first $\mathrm{OH} \ldots \mathrm{O} \mathrm{H}$-bond closer to the $\mathrm{H}^{+} \mathrm{Ox}$ positive charge is much further red shifted compared to the remaining $v_{b}$ oscillator of the second $\mathrm{OH}$... H H-bond $\left(3046\right.$ vs. $\left.3374 \mathrm{~cm}^{-1}\right)$.

The IRPD spectrum of $\mathrm{H}^{+} \mathrm{Ox}-\mathrm{W}_{3}$ is compared in Figure 7 to the IR spectra computed for the two considered isomers. The IRPD spectrum exhibits four major bands at 3743 (A), 3654 (B), 3348 (D1), and $3178(E) \mathrm{cm}^{-1}$. Transition D1 has a blue-shaded contour, which is characteristic of a proton-donor stretch band. These four bands are readily assigned to the transitions of the most stable $\mathrm{H}^{+} \mathrm{Ox}-\mathrm{W}_{3}(\mathrm{~b})$ isomer predicted at $3744\left(v_{3}\right)$, $3654\left(v_{1}\right), 3384$ (antisymmetric $v_{\mathrm{OH}}{ }^{\mathrm{b}}$ ), 3349 (symmetric $v_{\mathrm{OH}}{ }^{\mathrm{b}}$ ), and 3160 (most intense $v_{\mathrm{CH}}$ ), respectively. Additionally, the weak feature $X$ at $3242 \mathrm{~cm}^{-1}$ is tentatively assigned to $2 \beta_{\mathrm{OH}}$ of the water ligands. The good agreement between experimental and computed IR spectra demonstrates that the branched isomer dominates the $\mathrm{H}^{+} \mathrm{Ox}-\mathrm{W}_{3}$ population, consistent with its higher $D_{0}$ value. In addition to the major peaks, the IRPD spectrum exhibits two weaker and less resolved bands at 3707 (C) and 3050 (D2) $\mathrm{cm}^{-1}$, which indicate a very weak population of the less stable $\mathrm{H}^{+} \mathrm{Ox}-\mathrm{W}_{3}(\mathrm{I})$ isomer. The intensity of band $\mathrm{C}$, which is assigned to the two overlapping and nearly degenerate $v_{\mathrm{f}}$ modes of $\mathrm{H}^{+} \mathrm{Ox}-\mathrm{W}_{3}(\mathrm{I})$ predicted at 3717 and $3715 \mathrm{~cm}^{-1}$, is dramatically reduced as compared to $\mathrm{H}^{+} \mathrm{Ox}-\mathrm{W}_{2}$, confirming the predominant population of the branched 
isomer. The remaining weak feature D2 is attributed to the $v_{\mathrm{OH}}{ }^{\mathrm{b}}$ mode predicted at $3046 \mathrm{~cm}^{-1}$ with high intensity $(1548 \mathrm{~km} / \mathrm{mol})$.

\section{$4.5 \mathrm{H}^{+} \mathrm{Ox}-\mathrm{W}_{4}$}

The potential energy surface becomes substantially more complex for increasing degree of hydration. Thus, the search for low-energy minima of $\mathrm{H}^{+} \mathrm{Ox}-\mathrm{W}_{4}$ is less complete. To this end, we consider the four lowenergy $\mathrm{H}^{+} \mathrm{Ox}-\mathrm{W}_{4}$ structures shown in Figure 6 . The branched and linear $\mathrm{H}^{+} \mathrm{Ox}-\mathrm{W}_{4}(\mathrm{~b} / \mathrm{l})$ isomers feature a $\mathrm{NH}$...O type $\mathrm{H}$-bond of $\mathrm{H}^{+} \mathrm{Ox}$ to the $\mathrm{H}$-bonded $\mathrm{W}_{4}$ network and are obtained by simply adding a fourth $\mathrm{W}$ ligand in the outermost shell of the two corresponding $n=3$ isomers. As for the $n=3$ case, the branched structure is more stable than the linear structure for $n=4$, because the $W$ ligands are closer to the excess proton $\left(D_{0}=17067\right.$ vs. $\left.16425 \mathrm{~cm}^{-1}\right)$. For these structures, the cooperativity in binding energy amounts to 7764 and $7022 \mathrm{~cm}^{-1}(81.5$ and $74.7 \%)$. In the other two cyclic $\mathrm{H}^{+} \mathrm{Ox}-\mathrm{W}_{4}(\mathrm{c} 1 / \mathrm{c} 2)$ isomers, the first three $\mathrm{W}$ molecules form a $\mathrm{H}$-bonded solvent ring involving the $\mathrm{NH}$ and adjacent $\mathrm{CH}$ groups of $\mathrm{H}^{+} \mathrm{Ox}(\mathrm{C} 2 \mathrm{H}$ or $\mathrm{C} 4 \mathrm{H})$ as proton donors in $\mathrm{NH}$.. O and $\mathrm{CH}$...O type $\mathrm{H}$-bonds. The remaining fourth $\mathrm{W}$ ligand is then $\mathrm{H}$-bonded with one of the peripheral $\mathrm{W}$ ligands in the second hydration shell. Thus, the cyclic isomers have one more $\mathrm{H}$-bond than the branched and linear isomers. As a result of the additional $\mathrm{CH}$... O H-bond, the $\mathrm{H}^{+} \mathrm{Ox}-\mathrm{W}_{4}(\mathrm{c} 1)$ isomer has the highest stability $\left(D_{0}=17169 \mathrm{~cm}^{-1}\right)$ of all isomers considered. $\mathrm{H}^{+} \mathrm{Ox}-\mathrm{W}_{4}(\mathrm{c} 2)$ has a somewhat lower binding energy $\left(D_{0}=16495 \mathrm{~cm}^{-1}\right)$, partly because the $\mathrm{C} 4 \mathrm{H}$ group is less acidic than the $\mathrm{C} 2 \mathrm{H}$ group, ${ }^{60}$ leading to a slightly weaker and longer $\mathrm{CH} \ldots \mathrm{O} \mathrm{H}$-bond $\left(R_{\mathrm{CH} \ldots \mathrm{O}}=2.077\right.$ vs $\left.2.062 \AA\right)$. On the other hand, the strong $\mathrm{NH} \ldots \mathrm{O}$ ionic $\mathrm{H}$-bond in the cyclic isomers is somewhat weaker than in the branched and linear isomers $\left(R_{\mathrm{NH} \ldots \mathrm{O}}=1.539\right.$ and $1.542 \AA$ vs. 1.389 and $\left.1.454 \AA\right)$, because of the additional constraints on the $\mathrm{H}$-bonded solvent network imposed by the additional $\mathrm{CH}$... O H-bond. In fact, no cyclic stable structure is found for the cluster size $n=3$. Similarly, no cyclic $n=4$ structure with all four $\mathrm{W}$ ligands participating in the water ring is obtained. Except for $\mathrm{H}^{+} \mathrm{Ox}-\mathrm{W}_{4}(\mathrm{l})$, all structures feature a three-coordinated $\mathrm{W}$ ligand. However, its nature in terms of number of donor and acceptor $\mathrm{H}$-bonds is different for different isomers (double-donor singleacceptor or single-donor double-acceptor). The $v_{\mathrm{OH}}{ }^{\mathrm{b}}$ frequencies of the $\mathrm{W}_{4}$ network within these structures span a wide range and depend sensitively on the respective solvation environment. In comparison to the free $v_{\mathrm{CH}}$ modes of the linear and branched isomers, the IR intensity of the $\mathrm{H}$-bonded $v_{\mathrm{CH}}{ }^{\mathrm{b}}$ mode of the cyclic structures is significantly enhanced with a concomitant red shift of its frequency $\left(v_{\mathrm{CH}}{ }^{\mathrm{b}}=3027\right.$ and $3104 \mathrm{~cm}^{-1}$ for the cyclic isomers, $3155<v_{\mathrm{CH}}<3190 \mathrm{~cm}^{-1}$ for the noncyclic structures).

The proton affinity of $\mathrm{W}_{n}$ clusters increases with cluster size $n$ (PA=691, 808, 862, and $900 \mathrm{~kJ} / \mathrm{mol}$ for $n=1$ $4)^{59,79,83}$ and exceeds the value for $\mathrm{N}$-protonated $\mathrm{H}^{+} \mathrm{Ox}(\mathrm{PA}=876 \mathrm{~kJ} / \mathrm{mol})$ for clusters larger than $n \geq 4$ by more than $20 \mathrm{~kJ} / \mathrm{mol}$ ( or $1700 \mathrm{~cm}^{-1}$ ). Hence, from these values alone, one may expect intracluster proton transfer from $\mathrm{H}^{+} \mathrm{Ox}$ to $\mathrm{W}_{n}$ in $\mathrm{H}^{+} \mathrm{Ox}-\mathrm{W}_{n}$ clusters to occur for $n>3$, leading to the formation of $\mathrm{Ox}-\mathrm{H}^{+} \mathrm{W}_{n}$ clusters. However, in addition to the PA values one must also consider the difference in the intermolecular solvation energies, which may partly compensate for the PA difference. ${ }^{84-87}$ In addition, the $\mathrm{W}_{n}$ structures in $\mathrm{H}^{+} \mathrm{Ox}-\mathrm{W}_{n}$ and the $\mathrm{H}^{+} \mathrm{W}_{n}$ structures in $\mathrm{Ox}-\mathrm{H}^{+} \mathrm{W}_{n}$ differ from those of bare $\mathrm{W}_{n}$ and $\mathrm{H}^{+} \mathrm{W}_{n}$, so that the effective PA values are modified accordingly. For this reason, the four $\mathrm{H}^{+} \mathrm{Ox}-\mathrm{W}_{4}$ isomers shown in Figure 6 are actually quite stable non-proton-transferred isomers, although the PA values of bare $\mathrm{W}_{4}$ and $\mathrm{Ox}$ alone clearly suggest exothermic intracluster proton transfer. The most stable proton-transferred $\mathrm{Ox}-\mathrm{H}^{+} \mathrm{W}_{4}(1 / 2)$ structures shown in 
Figure 6 have indeed binding energies $\left(D_{0}=17054\right.$ and $\left.16109 \mathrm{~cm}^{-1}\right)$ comparable to those of the $\mathrm{H}^{+} \mathrm{Ox}-\mathrm{W}_{4}$ isomers but do not reach the stabilization of the $\mathrm{H}^{+} \mathrm{Ox}-\mathrm{W}_{4}(\mathrm{c} 1)$ isomer, which remains the global minimum. These two $O x-H^{+} W_{4}(1 / 2)$ structures differ in the position of the neutral Ox ligand in the hydration shell of $\mathrm{H}^{+} \mathrm{W}_{4}$. While in $\mathrm{Ox}-\mathrm{H}^{+} \mathrm{W}_{4}(1)$ the Ox ligand is a member of the Eigen-type ion core with direct contact to the central $\mathrm{H}_{3} \mathrm{O}^{+}$ion, it binds in $\mathrm{Ox}-\mathrm{H}^{+} \mathrm{W}_{4}(2)$ in the first solvation shell to a distorted $\mathrm{H}_{9} \mathrm{O}_{4}{ }^{+}$core, thus leading to a smaller total binding energy. From the bare consideration of the computed dipole moments of $\mathrm{Ox}$ and $\mathrm{W}$ $(1.54$ and $1.85 \mathrm{D})$ and the resulting charge-dipole interaction, one would actually expect $\mathrm{Ox}-\mathrm{H}^{+} \mathrm{W}_{4}(2)$ to be more stable than $\mathrm{Ox}-\mathrm{H}^{+} \mathrm{W}_{4}(1)$. Apparently, the larger cooperativity of the $\mathrm{H}$-bonded network in $\mathrm{Ox}-\mathrm{H}^{+} \mathrm{W}_{4}(1)$ overrides this difference in electrostatic attraction and brings the Ox ring into the first solvation shell of $\mathrm{H}_{3} \mathrm{O}^{+}$. As a result, the $\mathrm{OH} \ldots \mathrm{N}$ ionic $\mathrm{H}$-bond in $\mathrm{Ox}-\mathrm{H}^{+} \mathrm{W}_{4}(1)$ is much stronger than in $\mathrm{Ox}-\mathrm{H}^{+} \mathrm{W}_{4}(2), R_{\mathrm{OH} \ldots \mathrm{N}}=1.438$ vs. $1.621 \AA$. Interestingly, the $\mathrm{Ox}-\mathrm{H}^{+} \mathrm{W}_{4}(1)$ and $\mathrm{H}^{+} \mathrm{Ox}-\mathrm{W}_{4}(\mathrm{~b})$ isomers are structurally very similar except for the position of the proton. Both nearly isoenergetic minima $\left(\Delta E_{0}=115 \mathrm{~cm}^{-1}\right)$ are separated by only small barriers of less than $200 \mathrm{~cm}^{-1}$ for proton transfer along the $\mathrm{N} \ldots \mathrm{H}^{+} \ldots \mathrm{O}$ coordinate, suggesting that the zero-point energy level lies above the transition state for this slightly asymmetric double-minimum potential (Figure S5 in the supporting information), leading to a single species with a largely delocalized shared proton.

Unlike the smaller $\mathrm{H}^{+} \mathrm{Ox}-\mathrm{W}_{n \leq 3}$ clusters, the IRPD spectrum is more congested for $n=4$ (Figure 1 and 8 ). The broad feature below $3500 \mathrm{~cm}^{-1}$ shows few unresolved and strongly overlapping bands, which are compatible with the simulated spectra of all considered isomers. The transitions $E$ and $X$ at 3180 and $3247 \mathrm{~cm}^{-1}$, respectively, are consistent with the band positions of the $n \leq 3$ clusters. Consequently, these two features are assigned to the $v_{\mathrm{CH}}$ and $2 \beta_{\mathrm{OH}}$ vibrations, respectively. However, this spectral range also exhibits contributions from the $v_{\mathrm{OH}}{ }^{b}$ modes of both $\mathrm{H}^{+} \mathrm{Ox}-\mathrm{W}_{4}$ and $\mathrm{Ox}-\mathrm{H}^{+} \mathrm{W}_{4}$ type structures. The new and relatively weak feature at $3567 \mathrm{~cm}^{-1}(\mathrm{Y})$ can be explained only by the $v_{\mathrm{OH}}{ }^{\mathrm{b}}$ mode of the $\mathrm{W}$ ligand involved in the $\mathrm{CH}$...W H-bond of the cyclic $\mathrm{H}^{+} \mathrm{Ox}-\mathrm{W}_{4}(\mathrm{c} 2)$ isomer. Similarly, the weakly resolved transition $\mathrm{H}\left(3084 \mathrm{~cm}^{-1}\right)$, which is absent in the smaller $n=2-3$ clusters, is attributed to the $\mathrm{H}$-bonded red-shifted $v_{\mathrm{CH}}{ }^{\mathrm{b}}$ modes of the two considered cyclic structures. These observations may be taken as experimental evidence for the competitive stability of cyclic $\mathrm{H}^{+} \mathrm{Ox}-\mathrm{W}_{4}$ isomers predicted by the DFT calculations. Similar to the $n=2-3$ clusters, the transitions at 3651 (B), 3715 (C), and $3741(\mathrm{~A}) \mathrm{cm}^{-1}$ are attributed to $v_{1}, v_{\mathrm{f}}$, and $v_{3}$ modes, which are characteristic of all calculated structures. Interestingly, the experimental intensity of band $C$ increases compared to $n=3$. In general, it is difficult to exclude any of the calculated structures, and other isomers not considered in the calculations may also contribute. Despite the higher $\mathrm{PA}$ of $\mathrm{W}_{4}$ in comparison to $\mathrm{Ox}$, no unequivocal signature of the intracluster proton transfer is detected. However, proton-transferred structures are energetically comparable to the non-proton-transferred structures. Thus, we assume the presence of both types of geometries in our the ion source.

\subsection{Cluster Growth}

The analysis of the IRPD spectra $\mathrm{H}^{+} \mathrm{Ox}-\mathrm{W}_{n}$ with the aid of DFT calculations provides a clear picture of the cluster growth and the initial microhydration steps of $\mathrm{H}^{+} \mathrm{Ox}$. Clearly, the formation of a $\mathrm{H}$-bonded $\mathrm{W}_{n}$ solvent network attached to the acidic $\mathrm{NH}$ group of $\mathrm{N}$-protonated $\mathrm{H}^{+} \mathrm{Ox}$ is energetically strongly favoured over interior ion solvation because of the large cooperative effects of ionic $\mathrm{H}$-bonding. The most stable computed $\mathrm{H}^{+} \mathrm{Ox}-$ 
$W_{n}$ clusters $\mathrm{H}^{+} \mathrm{Ox}-\mathrm{W}(\mathrm{H}), \mathrm{H}^{+} \mathrm{Ox}-\mathrm{W}_{2}(\mathrm{H}), \mathrm{H}^{+} \mathrm{Ox}-\mathrm{W}_{3}(\mathrm{~b})$, and $\mathrm{H}^{+} \mathrm{Ox}-\mathrm{W}_{4}(\mathrm{c} 1)$ for $n=1-4$ are consistent with the experimental IRPD spectra, and the population of the $n=1-3$ clusters are strongly dominated by a single isomer corresponding to the global minimum. For $n=4$, several low-energy isomers compet,. In particular, cyclic structures with a weak second $\mathrm{H}$-bond contact $(\mathrm{CH} \ldots \mathrm{O})$ are observed as new low-energy isomers. Because the proton affinity of $\mathrm{W}_{n}$ clusters increases with cluster size (PA=691, 808, 862, $900 \mathrm{~kJ} / \mathrm{mol}$ for $n=1$ 4), its $\mathrm{NH} \ldots \mathrm{O}$ ionic $\mathrm{H}$-bond to the acidic $\mathrm{NH}$ group of $\mathrm{N}$-protonated $\mathrm{H}^{+} \mathrm{O}$ x becomes stronger and shorter $\left(R_{\mathrm{NH} \ldots \mathrm{O}}=1.659>1.555>1.454>1.389 \AA\right.$ for $n=1-4$; we consider here the $\mathrm{H}^{+} \mathrm{Ox}-\mathrm{W}_{4}(\mathrm{~b})$ isomer, because its $\mathrm{H}$ bond network is not perturbed by the $\mathrm{CH}$... O H-bond), leading to a pronounced increasing red shift in $v_{\mathrm{NH}}{ }^{\mathrm{b}}$ $\left(\Delta v_{N H}{ }^{b}=-563,-892,-1339,-1671 \mathrm{~cm}^{-1}\right.$ for $n=1-4$, Figure 9). The red shift is so large that the $v_{N H}{ }^{b}$ transition is here only observed for $n=1$, because the intensity of the employed IR-OPO laser is too low below $2600 \mathrm{~cm}^{-1}$ to drive IRPD of the strongly bonded W ligands. The total binding energy increases as $D_{0}=6094<10278<$ $13908<17067 \mathrm{~cm}^{-1}$ for $n=1-4$, yielding incremental hydration energies of $6094,4184,3630$, and $3159 \mathrm{~cm}^{-1}$, which are all substantially larger than the dissociation energy of the $W_{2}$ dimer $\left(1108 \mathrm{~cm}^{-1}\right)$, illustrating the large polarization effect of the excess $\mathrm{H}^{+}$on the $\mathrm{W}_{n}$ network. The increasing strength of the ionic $\mathrm{NH}$... bond as a function of hydration is accompanied by increasing charge transfer to the solvent cluster $(\Delta q=0.060,0.091,0.129$, and 0.161 e for $n=1-4$, Figure $S 2$ in the supporting information). This trend is in line with the $E^{(2)}$ energies and $\rho^{*}$ values of the $\mathrm{NH} \ldots \mathrm{O} \mathrm{H}$-bond derived from $\mathrm{NBO}$ and $\mathrm{NCl}$ calculations $\left(E^{(2)}=106.1,161.5,241.7,318.5 \mathrm{~kJ} / \mathrm{mol} ;-\rho^{*}=0.0498,0.0656,0.0862,0.1033\right.$ a.u. for $n=1-4$, Figures $\mathrm{S} 6$ and $\mathrm{S} 7$ in the supporting information). For clusters with $n \geq 4$, proton transfer for $\mathrm{H}^{+} \mathrm{Ox}$ to the $\mathrm{W}_{n}$ cluster becomes energetically competitive according to the DFT calculations and the comparison of proton affinity values (Figure S8 in the supporting information). Experimentally, the IRPD spectrum of $n=4$ is not of sufficient resolution to decide this aspect. Clearly, although solvation energy is in favour of protonation of Ox, the most stable clusters with larger $n$ will ultimately be of the type $O x-\mathrm{H}^{+} \mathrm{W}_{n}$ with a neutral Ox ligand being located on the surface, because the excess proton in $\mathrm{H}^{+} \mathrm{W}$ can be stabilized more efficiently.

Tagging of the $\mathrm{H}^{+} \mathrm{Ox}-\mathrm{W}_{1-2}$ clusters with $\mathrm{N}_{2}$ significantly reduces their internal energy, resulting in narrower transitions in IRPD spectra with higher resolution. The tagged water complexes prefer $\mathrm{N}_{2}$ attachment through $\mathrm{H}$-bond formation adjacent to the positive charge.

\subsection{Comparison to Neutral Ox-W}

To evaluate the effects of protonation of $\mathrm{Ox}$ on the microhydration structure, it is instructive to compare the properties of $\mathrm{H}^{+} \mathrm{Ox}-\mathrm{W}_{n}$ with those of the neutral Ox- $\mathrm{W}_{n}$ clusters. Unfortunately, no experimental information is available for any $O x-L_{n}$ cluster and computational studies are limited to the Ox-W dimer. ${ }^{48}$ In the global minimum of $\mathrm{Ox}-\mathrm{W}, \mathrm{W}$ binds to the in-plane lone pair of the basic $\mathrm{N}$ atom of $\mathrm{Ox}$ via a linear $\mathrm{OH}$... $\mathrm{N} \mathrm{H}$-bond $\left(D_{0}=1697 \mathrm{~cm}^{-1}, R_{\mathrm{OH} \ldots \mathrm{N}}=1.951 \AA\right.$, Figure $\mathrm{S} 1$ in the supporting information), which is indeed much weaker than the ionic $\mathrm{NH} \ldots \mathrm{O} \mathrm{H}$-bond in the $\mathrm{N}$-protonated $\mathrm{H}^{+} \mathrm{Ox}-\mathrm{W}(\mathrm{H}) \operatorname{dimer}\left(D_{0}=6094 \mathrm{~cm}^{-1}, R_{\mathrm{NH} \ldots \mathrm{O}}=1.659 \AA\right)$, indicating the drastic change of protonation on the interaction potential with respect to both the global minimum structure (orientation of the $W$ ligand) and the interaction strength. Stable structures with other possible binding sites of $W$ to neutral Ox (e.g., $\pi$ and $O$ ) do not converge at the B3LYP-D3/aug-cc-pVTZ level employed herein. In particular, the local minimum obtained in Ref. 48 at the MP2 and B3LYP levels using the 
smaller $6-31+\mathrm{G}^{*}$ basis set (with a $\mathrm{C} 5 \mathrm{H} \ldots \mathrm{O}$ and $\mathrm{OH} \ldots \mathrm{O} \mathrm{H}$-bond) can not be reproduced herein at the higher computational level with the much larger basis set and proper inclusion of dispersion. Interestingly, the lower-level calculations predict for the Ox-W global minimum a much longer $\mathrm{H}$-bond $\left(R_{\mathrm{OH}} \ldots \mathrm{N}=2.010 \AA\right)$, along with a much higher binding energy $\left(D_{0} \sim 2550 \mathrm{~cm}^{-1}\right)^{48}$ than our more reliable B3LYP-D3/aug-cc-pVTZ approach.

\subsection{Comparison to $\mathrm{H}^{+} \mathrm{Ox}-\mathrm{L}_{n}$ Clusters with Aprotic Ligands}

The microhydration process of $\mathrm{H}^{+} \mathrm{Ox}$ with protic, hydrophilic, and dipolar $\mathrm{W}$ molecules differs qualitatively from solvation with aprotic, hydrophobic, and nonpolar $(L=A r)$ or quadrupolar $\left(L=N_{2}\right)$ ligands characterized previously by the same experimental and computational approach. ${ }^{60}$ For the latter solvents, the L...L interaction is much weaker than the $\mathrm{H}^{+} \mathrm{Ox}$...L interaction $\left(<100 \mathrm{~cm}^{-1}\right)^{62}$ and no strong $\mathrm{H}$-bonded network can be formed. As a result, $\mathrm{H}^{+} \mathrm{Ox}-\left(\mathrm{Ar} / \mathrm{N}_{2}\right)_{n}$ clusters prefer interior ion solvation, in which individual ligands are attached to the $\mathrm{H}^{+} \mathrm{Ox}$ cation core, first by $\mathrm{H}$-bonding to the $\mathrm{NH}$ group, and subsequently by attachment to the less stable $\pi$ and $\mathrm{CH}$ binding sites. In contrast, $\mathrm{H}^{+} \mathrm{Ox}-\mathrm{W}_{n}$ clusters prefer the formation of the $\mathrm{H}$-bonded solvent network, because of the strong cooperativity of $\mathrm{H}$-bonding discussed above. Common to all $\mathrm{H}^{+} \mathrm{Ox}-\mathrm{L}$ dimers is that the global minimum on the potential is the $\mathrm{H}$-bonded $\mathrm{H}^{+} \mathrm{Ox}-\mathrm{L}(\mathrm{H})$ structure with a linear $\mathrm{NH} \ldots \mathrm{L}$ ionic $\mathrm{H}$-bond of the neutral ligand to the highly acidic proton of the $\mathrm{NH}$ group of $\mathrm{H}^{+} \mathrm{Ox}$. Again, the interaction strength is strongly correlated with the $P A$ of $L\left(P A=369<494<691 \mathrm{~kJ} / \mathrm{mol}\right.$ for $\mathrm{Ar}, \mathrm{N}_{2}$, and W), ${ }^{59}$ $D_{0}=891<1597<6094 \mathrm{~cm}^{-1},{ }^{60}$ as illustrated in Figure 9. As a result, the $\mathrm{NH} \ldots \mathrm{L}$ ionic $\mathrm{H}$-bond to the acidic $\mathrm{NH}$ group of $\mathrm{N}$-protonated $\mathrm{H}^{+} \mathrm{Ox}$ becomes stronger and shorter $\left(R_{\mathrm{NH} \ldots \mathrm{L}}=2.420>2.031>1.659 \AA\right)$, leading to an increasing predicted red shift in $v_{\mathrm{NH}}{ }^{\mathrm{b}}\left(\Delta v_{\mathrm{NH}}{ }^{\mathrm{b}}=-70,-157,-546 \mathrm{~cm}^{-1}\right)$, consistent with the observed values (-52, 126, -611 (considering $\mathrm{F} 3$ ) $\mathrm{cm}^{-1}$ ). This trend in $\mathrm{H}$-bond strength is also visible in the charge transfer from $\mathrm{H}^{+} \mathrm{Ox}$ to $\mathrm{L}(\Delta q=0.017,0.028,0.060 \mathrm{e})$, the $E^{(2)}$ energies $(13.7,42.2,106.1 \mathrm{~kJ} / \mathrm{mol})$ and the $\rho^{*}$ values $(-0.013$, $-0.022,-0.0498$ a.u.).

\section{Conclusions}

In this work, we characterized microhydrated clusters of $\mathrm{H}^{+} \mathrm{Ox}$ by IR photodissociation spectroscopy of size-selected $\mathrm{H}^{+} \mathrm{Ox}-\mathrm{W}_{n}$ clusters and dispersion-corrected DFT calculations to determine for the first time the protonation site and the most stable structure of the solvation network of this prototypical protonated azole ring. Tagging of the hydrated cluster up to $n=2$ with $\mathrm{N}_{2}$ results in internally colder clusters and thus spectra with higher resolution. Systematic shifts in the $\mathrm{OH}, \mathrm{NH}$, and $\mathrm{CH}$ stretch frequencies as a function of the cluster size provide a consistent picture of the sequential cluster growth. The salient results may be summarized as follows. Protonation of $\mathrm{Ox}$ in the $\mathrm{H}_{2}$-containing plasma occurs at the most basic $\mathrm{N}$ atom of the heterocyclic ring. The spectra of the $n=1-3$ clusters are dominated by the most stable isomer predicted by the DFT calculations. Microhydration of $\mathrm{H}^{+} \mathrm{Ox}$ occurs by solvating the acidic $\mathrm{NH}$ proton of $\mathrm{H}^{+} \mathrm{Ox}$ with a $\mathrm{H}$ bonded $\mathrm{W}_{n}$ cluster via a strong ionic $\mathrm{NH}$... O H-bond. The formation of such $\mathrm{H}$-bonded networks is strongly cooperative and the strength of the $\mathrm{NH} \ldots \mathrm{O}$ bond increases with $n$, because the proton affinity of $\mathrm{W}_{n}$ increases with size. At the cluster size $n=4$, structures with nearly barrierless proton transfer to the solvent, $\mathrm{Ox}-\mathrm{H}^{+} \mathrm{W}_{4}$, are predicted to become energetically competitive with structures of the type $\mathrm{H}^{+} \mathrm{Ox}-\mathrm{W}_{4}$, because the larger solvation energy can compensate for the difference in proton affinity of Ox and $\mathrm{W}_{4}(\sim 25 \mathrm{~kJ} / \mathrm{mol})$. 
Indeed, in contrast to the $n=1-3$ spectra, the $n=4$ spectrum is significantly more congested indicating the presence of more than one isomer, including the likely formation of proton-transferred structures. We expect that in the most stable clusters with $n \geq 5$ a neutral $\mathrm{Ox}$ ring binds at the surface of a $\mathrm{H}^{+} \mathrm{W}_{n}$ cluster, and this intracluster proton transfer is an important process toward understanding the physiological activity of Oxbearing biomolecules in microhydrated environments. Comparison of $\mathrm{H}^{+} \mathrm{Ox}-\mathrm{W}_{n}$ with the previously studied $\mathrm{H}^{+} \mathrm{Ox}-\mathrm{L}_{n}$ clusters with $\mathrm{L}=\mathrm{Ar}$ and $\mathrm{N}_{2}$ reveals importan differences in the solvation of $\mathrm{H}^{+} \mathrm{Ox}$ with hydrophilic and hydrophobic ligands. While the dipolar protic $\mathrm{W}$ ligands form a $\mathrm{H}$-bonded solvent network attached to the $\mathrm{NH}$ proton of $\mathrm{H}^{+} \mathrm{Ox}$, the aprotic nonpolar and quadrupolar $\mathrm{Ar}$ and $\mathrm{N}_{2}$ ligands prefer interior ion solvation by attachment of individual ligands around the heterocyclic aromatic cation. In all cases, the global minimum of the $\mathrm{H}^{+} \mathrm{Ox}-\mathrm{L}$ dimer features a linear $\mathrm{NH} . . . \mathrm{L}$ ionic $\mathrm{H}$-bond, and the strength of this $\mathrm{H}$-bond increases in the order $\mathrm{Ar}<\mathrm{N}_{2}<\mathrm{W}$, in line with the increasing proton affinity of the ligand. This trend is also visible in the red shift of the proton donor stretch vibration $\left(v_{\mathrm{NH}}{ }^{\mathrm{b}}\right)$, as well as the computed binding energies and the NBO and $\mathrm{NCl}$ analyses. Finally, protonation of $\mathrm{Ox}$ has a strong impact on the interaction potential with $\mathrm{W}$, with respect to both its structure and binding energy. While $\mathrm{Ox}-\mathrm{W}$ has a weakly $\mathrm{H}$-bonded structure with $\mathrm{W}$ acting as proton donor in an $\mathrm{OH}$... N H-bond, $\mathrm{H}^{+} \mathrm{Ox}-\mathrm{W}$ features a strong ionic $\mathrm{NH}$... O H-bond with $\mathrm{W}$ being a proton acceptor. Such charge-induced structural changes are typical for (mono-)hydrated aromatic molecules. $^{10,62,68,85-92}$

\section{Acknowledgements}

This study was supported by Deutsche Forschungsgemeinschaft (DO 729/3-3).

\section{Supporting Information}

Additional optimized structures, energies, calculated IR spectra, NBO atomic charges, $E^{(2)}$ energies, and $\rho^{*}$ values of selected $\mathrm{H}^{+} \mathrm{Ox}-\mathrm{W}_{n}$ isomers and $\mathrm{Ox}-\mathrm{W}$, along with proton affinities of $\mathrm{W}_{n}$ and $\mathrm{Ox}$. 


\section{Figure Captions}

Figure 1. Comparison of IRPD spectra of $\mathrm{H}^{+} \mathrm{Ox}-\mathrm{W}_{n}(n=1-4)$ and $\mathrm{H}^{+} \mathrm{Ox}-\mathrm{W}_{n}-\mathrm{N}_{2} \quad(n=1-2)$ clusters measured between 2650 and $3820 \mathrm{~cm}^{-1}$. The positions of the transitions observed are listed in Table 1, along with the suggested vibrational and isomer assignments.

Figure 2. Optimized geometries of $\mathrm{W}, \mathrm{H}^{+} \mathrm{Ox}$ (N-protonated, with atomic numbering), and most stable isomers $\mathrm{H}^{+} \mathrm{Ox}-\mathrm{W}$ and $\mathrm{H}^{+} \mathrm{Ox}-\mathrm{W}-\mathrm{N}_{2}$ calculated at the B3LYP-D3/aug-cc-pVTZ level. Binding energies $\left(D_{0}\right)$ and bond lengths are given in $\mathrm{cm}^{-1}$ and $\AA$, respectively. Numbers in parentheses correspond to relative energies and free energies in $\mathrm{cm}^{-1}\left(E_{0}, G_{0}\right)$.

Figure 3. Comparison of measured IRPD spectra of $\mathrm{H}^{+} \mathrm{Ox}-\mathrm{W}$ and $\mathrm{H}^{+} \mathrm{Ox}-\mathrm{W}-\mathrm{N}_{2}$ to linear IR absorption spectra computed for the most stable isomers at the B3LYP-D3/aug-cc-pVTZ level. For comparison, the IR spectra calculated for bare $\mathrm{H}^{+} \mathrm{Ox}$ and $\mathrm{W}$ are also shown. The IR stick spectra are convoluted with Gaussian line profiles with $\mathrm{FWHM}=10 \mathrm{~cm}^{-1}$.

Figure 4. Optimized geometries of $\mathrm{W}_{2}, \mathrm{H}^{+} \mathrm{Ox}-\mathrm{W}_{2}$, and most stable isomers of $\mathrm{H}^{+} \mathrm{Ox}-\mathrm{W}_{2}-\mathrm{N}_{2}$ obtained at the B3LYP-D3/aug-cc-pVTZ level. Binding energies $\left(D_{0}\right)$ and bond lengths are given in $\mathrm{cm}^{-1}$ and $\AA$, respectively. Numbers in parentheses correspond to relative energies and free energies in $\mathrm{cm}^{-1}\left(E_{0}, G_{0}\right)$.

Figure 5. Comparison of measured IRPD spectra of $\mathrm{H}^{+} \mathrm{Ox}-\mathrm{W}_{2}$ and $\mathrm{H}^{+} \mathrm{Ox}-\mathrm{W}_{2}-\mathrm{N}_{2}$ to the linear IR absorption spectra computed for the most stable isomers at the B3LYP-D3/aug-cc-pVTZ level. For comparison, the IR spectra calculated for bare $W_{2}$ is also shown. The IR stick spectra are convoluted with Gaussian line profiles with $\mathrm{FWHM}=10 \mathrm{~cm}^{-1}$.

Figure 6. Optimized geometries of $\mathrm{H}^{+} \mathrm{Ox}-\mathrm{W}_{n}$ and $\mathrm{Ox}-\mathrm{H}^{+} \mathrm{W}_{n}$ clusters with $n=3$ and 4 obtained at the B3LYPD3/aug-cc-pVTZ level. Binding energies $\left(D_{0}\right)$ and bond lengths are given in $\mathrm{cm}^{-1}$ and $\AA$, respectively. Numbers in parentheses correspond to relative energies and free energies in $\mathrm{cm}^{-1}\left(E_{0}, G_{0}\right)$.

Figure 7. Comparison of measured IRPD spectrum of $\mathrm{H}^{+} \mathrm{Ox}-\mathrm{W}_{3}$ to the linear IR absorption spectra computed for the two most stable isomers at the B3LYP-D3/aug-cc-pVTZ level. The IR stick spectra are convoluted with Gaussian line profiles with $\mathrm{FWHM}=10 \mathrm{~cm}^{-1}$.

Figure 8. Comparison of measured IRPD spectrum of $\mathrm{H}^{+} \mathrm{Ox}-\mathrm{W}_{4}$ to the linear IR absorption spectra computed for the most stable isomers of $\mathrm{H}^{+} \mathrm{Ox}-\mathrm{W}_{4}$ and $\mathrm{Ox}-\mathrm{H}^{+} \mathrm{W}_{4}$ at the B3LYP-D3/aug-cc-pVTZ level. The IR stick spectra are convoluted with Gaussian line profiles with $\mathrm{FWHM}=10 \mathrm{~cm}^{-1}$.

Figure 9. Observed (filled circles) and calculated (open circles, B3LYP-D3/aug-cc-pVTZ) $v_{\mathrm{NH}}{ }^{\mathrm{b}}$ frequencies of the $\mathrm{H}$-bonded $\mathrm{H}^{+} \mathrm{Ox}-\mathrm{L}\left(\mathrm{L}=\mathrm{Ar}, \mathrm{N}_{2}, \mathrm{~W}\right)$ dimers and $\mathrm{H}^{+} \mathrm{Ox}-\mathrm{W}_{n}$ clusters as a the function of the PA of the ligands. For $n=4$, we consider both the $c 1$ and $b$ isomers. The $c 1$ isomer is most stable but its $\mathrm{NH}$...O H-bond is affected by the formation of the cyclic ring. The $\mathrm{NH} . . . \mathrm{O} \mathrm{H}$-bond of the less stable $\mathrm{b}$ isomer is not affected. 
Table 1. Positions and suggested vibrational and isomer assignments of the transitions observed in the IRPD spectra of $\mathrm{H}^{+} \mathrm{Ox}-\mathrm{W}_{n}(n=1-4)$ and $\mathrm{H}^{+} \mathrm{Ox}-\mathrm{W}_{n}-\mathrm{N}_{2}(n=1-2)$ clusters compared to frequencies of the most stable isomers calculated at the B3LYP-D3/aug-cc-pVTZ level. All values are given in $\mathrm{cm}^{-1}$. For comparison, spectral data of $\mathrm{W}_{n}$ with $n \leq 2$ are provided.

\begin{tabular}{|c|c|c|c|c|}
\hline & $\exp \left(\mathrm{cm}^{-1}\right)$ & calc $\left(\mathrm{cm}^{-1}\right)^{\mathrm{a}}$ & assignment & isomer \\
\hline $\mathrm{W}$ & $\begin{array}{l}3756^{b} \\
3657^{b}\end{array}$ & $\begin{array}{c}3757(63) \\
3658(5)\end{array}$ & $\begin{array}{l}v_{3} \\
v_{1}\end{array}$ & \\
\hline $\mathrm{W}_{2}$ & $\begin{array}{l}3746^{c} \\
3735^{c} \\
3654^{c} \\
3601^{c}\end{array}$ & $\begin{array}{l}3749(84) \\
3730(86) \\
3653(10) \\
3542(341)\end{array}$ & $\begin{array}{c}v_{3} \\
v_{\mathrm{f}} \\
v_{1} \\
v_{\mathrm{OH}}^{\mathrm{b}}\end{array}$ & \\
\hline$O x$ & $\begin{array}{l}3168^{d} \\
3148^{d}\end{array}$ & $\begin{array}{c}3170(0.4) \\
3137(2) \\
3144(0.9)\end{array}$ & $\begin{array}{l}v_{\mathrm{CH}} \\
v_{\mathrm{CH}} \\
v_{\mathrm{CH}}\end{array}$ & Ox \\
\hline $\mathrm{H}^{+} \mathrm{Ox}$ & $\begin{array}{l}3444 \pm 3^{e} \\
3205 \pm 5^{e} \\
3180 \pm 10^{e} \\
3170 \pm 10^{e}\end{array}$ & $\begin{array}{l}3446(202) \\
3181(27) \\
3161(40) \\
3149(69)\end{array}$ & $\begin{array}{l}v_{\mathrm{NH}}^{f} \\
v_{\mathrm{CH}} \\
v_{\mathrm{CH}} \\
v_{\mathrm{CH}}\end{array}$ & $\mathrm{H}^{+} \mathrm{Ox}(\mathrm{N})$ \\
\hline $\mathrm{H}^{+} \mathrm{Ox}-\mathrm{W}$ & $\begin{array}{l}\text { A } 3720 \\
\text { B } 3625 \\
X 3230 \\
\text { E } 3179 \\
\text { E } 3179 \\
\text { E } 3179 \\
\text { F1 } 3095 \\
\text { F2 } 2969 \\
\text { F3 } 2833\end{array}$ & $\begin{array}{c}3728(151) \\
3642(56) \\
3184(16) \\
3163(31) \\
3155(57) \\
2883(1840)\end{array}$ & $\begin{array}{c}v_{3} \\
v_{1} \\
2 \beta_{\mathrm{OH}} \\
v_{\mathrm{CH}} \\
v_{\mathrm{CH}} \\
v_{\mathrm{CH}} \\
v_{\mathrm{NH}}{ }^{\mathrm{b}}\end{array}$ & $\mathrm{H}^{+} \mathrm{Ox}-\mathrm{W}(\mathrm{H})$ \\
\hline $\mathrm{H}^{+} \mathrm{Ox}-\mathrm{W}-\mathrm{N}_{2}$ & $\begin{array}{l}\text { A } 3711 \\
\text { B } 3610 \\
\text { X } 3230 \\
\text { E } 3178 \\
\text { E } 3178 \\
\text { E } 3178 \\
\text { F } 2970\end{array}$ & $\begin{array}{l}3706(195) \\
3576(383) \\
3184(15) \\
3164(30) \\
3156(54) \\
2785(2209)\end{array}$ & $\begin{array}{c}v_{3} \\
v_{1} \\
2 \beta_{\mathrm{OH}} \\
v_{\mathrm{CH}} \\
v_{\mathrm{CH}} \\
v_{\mathrm{CH}} \\
v_{\mathrm{NH}}{ }^{\mathrm{b}}\end{array}$ & $\mathrm{H}^{+} \mathrm{Ox}-\mathrm{W}(\mathrm{H})-\mathrm{N}_{2}(\mathrm{H})$ \\
\hline $\mathrm{H}^{+} \mathrm{Ox}-\mathrm{W}_{2}$ & $\begin{array}{l}\text { A } 3745 \\
\text { C } 3705 \\
\text { B } 3649 \\
\text { D } 3338 \\
\text { X } 3247 \\
\text { E } 3179 \\
\text { E } 3179 \\
\text { E } 3179\end{array}$ & $\begin{array}{c}3739(124) \\
3712(115) \\
3651(31) \\
3267(1023) \\
\\
3185(14) \\
3164(27) \\
3158(48) \\
2554(2853)\end{array}$ & $\begin{array}{c}v_{3} \\
v_{\mathrm{f}} \\
v_{1} \\
v_{\mathrm{OH}}{ }^{\mathrm{b}} \\
2 \beta_{\mathrm{OH}} \\
v_{\mathrm{CH}} \\
v_{\mathrm{CH}} \\
v_{\mathrm{CH}} \\
v_{\mathrm{NH}}^{\mathrm{b}}\end{array}$ & $\mathrm{H}^{+} \mathrm{Ox}-\mathrm{W}_{2}(\mathrm{H})$ \\
\hline $\mathrm{H}^{+} \mathrm{Ox}-\mathrm{W}_{2}-\mathrm{N}_{2}$ & $\begin{array}{l}\text { A } 3742 \\
\text { C1 } 3707 \\
\text { C2 } 3667 \\
\text { B } 3657\end{array}$ & $\begin{array}{c}3741(121), 3739(122) \\
3712(116) \\
3643(422) \\
3653(42), 3650(30)\end{array}$ & $\begin{array}{l}v_{3} \\
v_{\mathrm{f}} \\
v_{\mathrm{f}} \\
v_{1}\end{array}$ & $\begin{array}{c}\mathrm{H}^{+} \mathrm{Ox}-\mathrm{W}_{2}(\mathrm{H})-\mathrm{N}_{2}(\mathrm{H} 1), \mathrm{H}^{+} \mathrm{Ox}-\mathrm{W}_{2}(\mathrm{H})-\mathrm{N}_{2}(\pi) \\
\mathrm{H}^{+} \mathrm{Ox}-\mathrm{W}_{2}(\mathrm{H})-\mathrm{N}_{2}(\pi) \\
\mathrm{H}^{+} \mathrm{Ox}-\mathrm{W}_{2}(\mathrm{H})-\mathrm{N}_{2}(\mathrm{H} 1) \\
\mathrm{H}^{+} \mathrm{Ox}-\mathrm{W}_{2}(\mathrm{H})-\mathrm{N}_{2}(\mathrm{H} 1), \mathrm{H}^{+} \mathrm{Ox}-\mathrm{W}_{2}(\mathrm{H})-\mathrm{N}_{2}(\pi)\end{array}$ \\
\hline
\end{tabular}




\begin{tabular}{|c|c|c|c|c|}
\hline & $\begin{array}{l}\text { D } 3312 \\
X 3253 \\
\text { E } 3174 \\
\text { E } 3174 \\
\text { E } 3174\end{array}$ & $\begin{array}{l}3185(14), 3186(13) \\
3164(26), 3165(25) \\
3159(46), 3161(47)\end{array}$ & $\begin{array}{l}v_{\mathrm{OH}}^{\mathrm{b}} \\
2 \beta_{\mathrm{OH}} \\
v_{\mathrm{CH}} \\
v_{\mathrm{CH}} \\
v_{\mathrm{CH}}\end{array}$ & $\begin{array}{l}\mathrm{H}^{+} \mathrm{Ox}-\mathrm{W}_{2}(\mathrm{H})-\mathrm{N}_{2}(\mathrm{H} 1), \mathrm{H}^{+} \mathrm{Ox}-\mathrm{W}_{2}(\mathrm{H})-\mathrm{N}_{2}(\pi) \\
\mathrm{H}^{+} \mathrm{Ox}-\mathrm{W}_{2}(\mathrm{H})-\mathrm{N}_{2}(\mathrm{H} 1), \mathrm{H}^{+} \mathrm{Ox}-\mathrm{W}_{2}(\mathrm{H})-\mathrm{N}_{2}(\pi) \\
\mathrm{H}^{+} \mathrm{Ox}-\mathrm{W}_{2}(\mathrm{H})-\mathrm{N}_{2}(\mathrm{H} 1), \mathrm{H}^{+} \mathrm{Ox}-\mathrm{W}_{2}(\mathrm{H})-\mathrm{N}_{2}(\pi)\end{array}$ \\
\hline $\mathrm{H}^{+} \mathrm{Ox}-\mathrm{W}_{3}$ & $\begin{array}{l}\text { A } 3743 \\
\text { C } 3707 \\
\text { C } 3707 \\
\text { B } 3654 \\
\text { D1 } 3348 \\
\text { D1 } 3348 \\
\text { X } 3242 \\
\text { E } 3178 \\
\text { E } 3178 \\
\text { E } 3178 \\
\text { D2 } 3050\end{array}$ & $\begin{array}{c}3744(230),{ }^{\dagger} 3745(115) \\
3717(84) \\
3715(115) \\
3654(47),{ }^{\dagger}, 3654(23) \\
3384(1362), 3374(702) \\
3349(521) \\
3185(12), 3185(12) \\
3164(22), 3164(24) \\
3160(40), 3159(45) \\
3046(1548)\end{array}$ & $\begin{array}{c}v_{3} \\
v_{\mathrm{f}} \\
v_{\mathrm{f}} \\
v_{1} \\
v_{\mathrm{OH}}{ }^{\mathrm{b}} \\
v_{\mathrm{OH}}{ }^{\mathrm{b}} \\
2 \beta_{\mathrm{OH}} \\
v_{\mathrm{CH}} \\
v_{\mathrm{CH}} \\
v_{\mathrm{CH}} \\
v_{\mathrm{OH}}^{\mathrm{b}}\end{array}$ & $\begin{array}{c}\mathrm{H}^{+} \mathrm{Ox}-\mathrm{W}_{3}(\mathrm{~b}), \mathrm{H}^{+} \mathrm{Ox}-\mathrm{W}_{3}(\mathrm{I}) \\
\mathrm{H}^{+} \mathrm{Ox}-\mathrm{W}_{3}(\mathrm{I}) \\
\mathrm{H}^{+} \mathrm{Ox}-\mathrm{W}_{3}(\mathrm{I}) \\
\mathrm{H}^{+} \mathrm{Ox}-\mathrm{W}_{3}(\mathrm{~b}), \mathrm{H}^{+} \mathrm{Ox}-\mathrm{W}_{3}(\mathrm{I}) \\
\mathrm{H}^{+} \mathrm{Ox}-\mathrm{W}_{3}(\mathrm{~b}), \mathrm{H}^{+} \mathrm{Ox}-\mathrm{W}_{3}(\mathrm{I}) \\
\mathrm{H}^{+} \mathrm{Ox}-\mathrm{W}_{3}(\mathrm{~b}) \\
\mathrm{H}^{+} \mathrm{Ox}-\mathrm{W}_{3}(\mathrm{~b}), \mathrm{H}^{+} \mathrm{Ox}-\mathrm{W}_{3}(\mathrm{I}) \\
\mathrm{H}^{+} \mathrm{Ox}-\mathrm{W}_{3}(\mathrm{~b}), \mathrm{H}^{+} \mathrm{Ox}-\mathrm{W}_{3}(\mathrm{I}) \\
\\
\mathrm{H}^{+} \mathrm{Ox}-\mathrm{W}_{3}(\mathrm{I})\end{array}$ \\
\hline $\mathrm{H}^{+} \mathrm{Ox}-\mathrm{W}_{4}$ & $\begin{array}{l}\text { A } 3741 \\
\text { A } 3741 \\
\text { C } 3715 \\
\text { C } 3715 \\
\text { C } 3715 \\
\text { B } 3651 \\
\text { B } 3651 \\
\text { Y } 3567 \\
\text { D1 } 3427 \\
\text { D1 } 3427 \\
\text { D2/X } 3247 \\
\text { D2 } 3247 \\
\text { E } 3180 \\
\text { E } 3180 \\
\text { E } 3180 \\
\text { H } 3084\end{array}$ & $\begin{array}{c}3749(113), 3742(121) \\
3745(112) \\
3722(90), 3726(121) \\
3709(110) \\
3692(95) \\
3657(22), 3653(29) \\
3655(22) \\
3562(357) \\
3401 \text { (502), } 3428(414) \\
3379(1113) \\
3161(1450), 3325(945) \\
3194(1179) \\
3185 \text { (10), } 3186(16) \\
3164(15), 3164(21) \\
3160(46) \\
3027(364)\end{array}$ & $\begin{array}{c}v_{3} \\
v_{3} \\
v_{\mathrm{f}} \\
v_{\mathrm{f}} \\
v_{\mathrm{f}} \\
v_{1} \\
v_{1} \\
v_{\mathrm{OH}}{ }^{\mathrm{b}} \\
v_{\mathrm{OH}}{ }^{\mathrm{b}} \\
v_{\mathrm{OH}}{ }^{\mathrm{b}} \\
v_{\mathrm{OH}} / 2 \beta_{\mathrm{OH}} \\
v_{\mathrm{OH}}{ }^{\mathrm{b}} \\
v_{\mathrm{CH}} \\
v_{\mathrm{CH}} \\
v_{\mathrm{CH}} \\
v_{\mathrm{CH}}{ }^{\mathrm{b}}\end{array}$ & $\begin{array}{c}\mathrm{H}^{+} \mathrm{Ox}-\mathrm{W}_{4}(\mathrm{~b}), \mathrm{H}^{+} \mathrm{Ox}-\mathrm{W}_{4}(\mathrm{c} 1) \\
\mathrm{H}^{+} \mathrm{Ox}-\mathrm{W}_{4}(\mathrm{~b}) \\
\mathrm{H}^{+} \mathrm{Ox}-\mathrm{W}_{4}(\mathrm{~b}), \mathrm{H}^{+} \mathrm{Ox}-\mathrm{W}_{4}(\mathrm{c} 1) \\
\mathrm{H}^{+} \mathrm{Ox}-\mathrm{W}_{4}(\mathrm{c} 1) \\
\mathrm{H}^{+} \mathrm{Ox}-\mathrm{W}_{4}(\mathrm{c} 1) \\
\mathrm{H}^{+} \mathrm{Ox}-\mathrm{W}_{4}(\mathrm{~b}), \mathrm{H}^{+} \mathrm{Ox}-\mathrm{W}_{4}(\mathrm{c} 1) \\
\mathrm{H}^{+} \mathrm{Ox}-\mathrm{W}_{4}(\mathrm{~b}) \\
\mathrm{H}^{+} \mathrm{Ox}-\mathrm{W}_{4}(\mathrm{c} 2) \\
\mathrm{H}^{+} \mathrm{Ox}-\mathrm{W}_{4}(\mathrm{~b}), \mathrm{H}^{+} \mathrm{Ox}-\mathrm{W}_{4}(\mathrm{c} 1) \\
\mathrm{H}^{+} \mathrm{Ox}-\mathrm{W}_{4}(\mathrm{~b}) \\
\mathrm{H}^{+} \mathrm{Ox}-\mathrm{W}_{4}(\mathrm{~b}), \mathrm{H}^{+} \mathrm{Ox}-\mathrm{W}_{4}(\mathrm{c} 1) \\
\mathrm{H}^{+} \mathrm{Ox}-\mathrm{W}_{4}(\mathrm{c} 1) \\
\mathrm{H}^{+} \mathrm{Ox}-\mathrm{W}_{4}(\mathrm{~b}), \mathrm{H}^{+} \mathrm{Ox}-\mathrm{W}_{4}(\mathrm{c} 1) \\
\mathrm{H}^{+} \mathrm{Ox}-\mathrm{W}_{4}(\mathrm{~b}), \mathrm{H}^{+} \mathrm{Ox}-\mathrm{W}_{4}(\mathrm{c} 1) \\
\mathrm{H}^{+} \mathrm{Ox}-\mathrm{W}_{4}(\mathrm{~b}) \\
\mathrm{H}^{+} \mathrm{Ox}-\mathrm{W}_{4}(\mathrm{c} 1)\end{array}$ \\
\hline
\end{tabular}

${ }^{\mathrm{a}} \mathrm{IR}$ intensities (in $\mathrm{km} / \mathrm{mol}$ ) are listed in parentheses.

${ }^{\mathrm{b}}$ Ref. 71.

${ }^{\mathrm{c}}$ Ref. 80, 81, 82.

${ }^{d}$ Ref. 46.

${ }^{\text {e }}$ Ref. 60.

${ }^{f}$ The intensities of the two nearly degenerate modes are added. 


\section{References}

(1) Pal, S. K.; Zewail, A. H. Dynamics of Water in Biological Recognition. Chem. Rev. 2004, 104, 2099-2123.

(2) Perrin, C. L.; Nielson, J. B. "Strong” Hydrogen Bonds in Chemistry and Biology. Annu. Rev. Phys. Chem. 1997, 48, 511-544.

(3) Zhong, D.; Pal, S. K.; Zewail, A. H. Biological Water: A Critique. Chem. Phys. Lett. 2011, 503, 1-11.

(4) Chaplin, M. Do We Underestimate the Importance of Water in Cell Biology? Nat. Rev. Mol. Cell Biol. 2006, 7, 861-866.

(5) Levy, Y.; Onuchic, J. N. Water Mediation in Protein Folding and Molecular Recognition. Annu. Rev. Biophys. Biomol. Struct. 2006, 35, 389-415.

(6) Ball, P. Water as an Active Constituent in Cell Biology. Chem. Rev. 2008, 108, 74-108.

(7) Bagchi, B. Water Dynamics in the Hydration Layer around Proteins and Micelles. Chem. Rev. 2005, 105, 3197-3219.

(8) Rasaiah, J. C.; Garde, S.; Hummer, G. Water in Nonpolar Confinement: From Nanotubes to Proteins and Beyond. Annu. Rev. Phys. Chem. 2008, 59, 713-740.

(9) Mattos, C. Protein-Water Interactions in a Dynamic World. Trends Biochem. Sci. 2002, 27, 203-208.

(10) Dopfer, O.; Fujii, M. Probing Solvation Dynamics around Aromatic and Biological Molecules at the Single-Molecular Level. Chem. Rev. 2016, 116, 5432-5463.

(11) Nandi, N.; Bhattacharyya, K.; Bagchi, B. Dielectric Relaxation and Solvation Dynamics of Water in Complex Chemical and Biological Systems. Chem. Rev. 2000, 100, 2013-2045.

(12) Eisenthal, K. B. Liquid Interfaces. Acc. Chem. Res. 1993, 26, 636-643.

(13) Bizzarri, A. R.; Cannistraro, S. Molecular Dynamics of Water at the Protein-Solvent Interface. J. Phys. Chem. B 2002, 106, 6617-6633.

(14) Makarov, V.; Pettitt, B. M.; Feig, M. Solvation and Hydration of Proteins and Nucleic Acids: A Theoretical View of Simulation and Experiment. Acc. Chem. Res. 2002, 35, 376-384.

(15) Li, Z.; Lazaridis, T. The Effect of Water Displacement on Binding Thermodynamics: Concanavalin A. J. Phys. Chem. B 2005, $109,662-670$.

(16) Ben-Naim, A. Molecular Recognition - Viewed through the Eyes of the Solvent. Biophys. Chem. 2002, 101-102, 309-319.

(17) de Vries, M. S.; Hobza, P. Gas-Phase Spectroscopy of Biomolecular Building Blocks. Annu. Rev. Phys. Chem. 2006, 58, 585612.

(18) Boyarkin, O. V. Cold Ion Spectroscopy for Structural Identifications of Biomolecules. Int. Rev. Phys. Chem. 2018, 37, 559-606.

(19) Nagornova, N. S.; Rizzo, T. R.; Boyarkin, O. V. Exploring the Mechanism of IR-UV Double-Resonance for Quantitative Spectroscopy of Protonated Polypeptides and Proteins. Angew. Chem. Int. Ed. 2013, 52, 6002-6005.

(20) Rizzo, T. R.; Stearns, J. A.; Boyarkin, O. V. Spectroscopic Studies of Cold, Gas-Phase Biomolecular lons. Int. Rev. Phys. Chem. 2009, 28, 481-515.

(21) Müller-Dethlefs, K.; Dopfer, O.; Wright, T. G. ZEKE Spectroscopy of Complexes and Clusters. Chem. Rev. 1994, 94, 18451871.

(22) Duncan, M. A. Spectroscopy of Metal Ion Complexes: Gas-Phase Models for Solvation. Annu. Rev. Phys. Chem. 2002, 48, 69-93.

(23) Bieske, E. J. Spectroscopic Studies of Anion Complexes and Clusters: A Microscopic Approach to Understanding Anion Solvation. Chem. Soc. Rev. 2003, 32, 231-237. Castleman, A. W.; Keesee, R. G. Ionic Clusters. Chem. Rev. 1986, 86, 589-618. 
(25) Bieske, E. J.; Dopfer, O. High-Resolution Spectroscopy of Cluster lons. Chem. Rev. 2000, 100, 3963-3998.

(26) Müller-Dethlefs, K.; Hobza, P. Noncovalent Interactions: A Challenge for Experiment and Theory. Chem. Rev. 2000, 100, 143168.

(27) Bagley, M. C.; Dale, J. W.; Merritt, E. A.; Xiong, X. Thiopeptide Antibiotics. Chem. Rev. 2005, 105, 685-714.

(28) Chiu, M. L.; Folcher, M.; Katoh, T.; Puglia, A. M.; Vohradsky, J.; Yun, B.-S.; Seto, H.; Thompson, C. J. Broad Spectrum Thiopeptide Recognition Specificity of the Streptomyces lividans TipAL Protein and Its Role in Regulating Gene Expression. J. Biol. Chem. 1999, 274, 20578-20586.

(29) Gürsoy, A.; Demirayak, Ş.; Çapan, G.; Erol, K.; Vural, K. Synthesis and Preliminary Evaluation of New 5-Pyrazolinone Derivatives as Analgesic Agents. Eur. J. Med. Chem. 2000, 35, 359-364.

(30) Bull, J. A.; Balskus, E. P.; Horan, R. A. J.; Langner, M.; Ley, S. V. Total Synthesis of Potent Antifungal Marine Bisoxazole Natural Products Bengazoles A and B. Chem. Eur. J. 2007, 13, 5515-5538.

(31) Boyd, R. E.; Press, J. B.; Rasmussen, C. R.; Raffa, R. B.; Codd, E. E.; Connelly, C. D.; Bennett, D. J.; Kirifides, A. L.; Gardocki, J. F.; Reynolds, B.; et al. $\alpha_{2}$ Adrenoceptor Agonists as Potential Analgesic Agents. 1. (Imidazolylmethyl)Oxazoles and -Thiazoles . J. Med. Chem. 1999, 42, 5064-5071.

(32) Kempf, D. J.; Sham, H. L.; Marsh, K. C.; Flentge, C. A.; Betebenner, D.; Green, B. E.; McDonald E.; Vasavanonda, S.; Saldivar, A.; Wideburg, N. E.; et al. Discovery of Ritonavir, a Potent Inhibitor of HIV Protease with High Oral Bioavailability and Clinical Efficacy. J. Med. Chem. 1998, 41, 602-617.

(33) Dinarello, C. A. Anti-Inflammatory Agents: Present and Future. Cell 2010, 140, 935-950.

(34) Li, Y.-M.; Milne, J. C.; Madison, L. L.; Kolter, R.; Walsh, C. T. From Peptide Precursors to Oxazole and Thiazole-Containing Peptide Antibiotics: Microcin B17 Synthase. Science 2002, 274, 1188-1193.

(35) Vijaya Kumar, E. K. S.; Kenia, J.; Mukhopadhyay, T.; Nadkarni, S. R. Methylsulfomycin I, a New Cyclic Peptide Antibiotic from a Streptomyces Sp. HIL Y-9420704. J. Nat. Prod. 1999, 62, 1562-1564.

(36) Sasahara, K.; Shimokawa, Y.; Hirao, Y.; Koyama, N.; Kitano, K.; Shibata, M.; Umehara, K. Pharmacokinetics and Metabolism of Delamanid, a Novel Anti-Tuberculosis Drug, in Animals and Humans: Importance of Albumin Metabolism In Vivo. Drug Metab. Dispos. 2015, 43, 1267-1276.

(37) Portmann, C.; Blom, J. F.; Kaiser, M.; Brun, R.; Jüttner, F.; Gademann, K. Isolation of Aerucyclamides C and D and Structure Revision of Microcyclamide 7806A: Heterocyclic Ribosomal Peptides from Microcystis Aeruginosa PCC 7806 and Their Antiparasite Evaluation. J. Nat. Prod. 2008, 71, 1891-1896.

(38) Andersson, I. E.; Batsalova, T.; Dzhambazov, B.; Edvinsson, L.; Holmdahl, R.; Kihlberg, J.; Linusson, A. Oxazole-Modified Glycopeptides That Target Arthritis-Associated Class II MHC Aq and DR4 Proteins. Org. Biomol. Chem. 2010, 8, 2931-2940.

(39) Jin, Z. Muscarine, Imidazole, Oxazole and Thiazole Alkaloids. Nat. Prod. Rep. 2016, 33, 1268-1317.

(40) Ceide, S. C.; Trembleau, L.; Haberhauer, G.; Somogyi, L.; Lu, X.; Bartfai, T.; Rebek, J. Synthesis of Galmic: A Nonpeptide Galanin Receptor Agonist. Proc. Natl. Acad. Sci. 2004, 101, 16727-16732.

(41) Haberhauer, G.; Drosdow, E.; Oeser, T.; Rominger, F. Structural Investigation of Westiellamide Analogues. Tetrahedron 2008, 64, 1853-1859.

(42) Siodłak, D.; Staś, M.; Broda, M. A.; Bujak, M.; Lis, T. Conformational Properties of Oxazole-Amino Acids: Effect of the Intramolecular N-H...N Hydrogen Bond. J. Phys. Chem. B 2014, 118, 2340-2350.

(43) Haberhauer, G.; Pintér, Á.; Oeser, T.; Rominger, F. Synthesis and Structural Investigation of $\mathrm{C}_{4}-$ and $\mathrm{C}_{2}$-Symmetric Molecular Scaffolds Based on Imidazole Peptides. Eur. J. Org. Chem. 2007, 1779-1792.

(44) Xia, X.; Tang, W.; He, S.; Kang, J.; Ma, H.; Li, J. Mechanism of Metamifop Inhibition of the Carboxyltransferase Domain of Acetyl-Coenzyme A Carboxylase in Echinochloa Crus-Galli. Sci. Rep. 2016, 6, 1-10. 
(45) Borello, E.; Zecchina, A.; Appiano, A. Infra-Red Spectra of Oxazole and Its Alkyl Derivatives-I. 1966, 22, 977-983

(46) Sbrana, G.; Castellucci, E.; Ginanneschi, M. Infra-Red and Raman Spectra of Five-Membered Heterocyclic MoleculesOxazole and Thiazole. Spectrochim. Acta A 1967, 23, 751-758.

(47) Hegelund, F.; Larsen, R. W.; Palmer, M. H. High-Resolution Infrared and Theoretical Study of Gaseous Oxazole in the 600$1400 \mathrm{Cm}^{-1}$ Region. J. Mol. Spectrosc. 2007, 241, 26-44.

(48) Civcir, P. Ü.; Kurtay, G.; Sarıkavak, K. Experimental and Theoretical Investigation of New Furan and Thiophene Derivatives Containing Oxazole, Isoxazole, or Isothiazole Subunits. Struct. Chem. 2017, 28, 773-790.

(49) Kaur, D.; Khanna, S. Intermolecular Hydrogen Bonding Interactions of Furan, Isoxazole and Oxazole with Water. Comput. Theor. Chem. 2011, 963, 71-75.

(50) Palmer, M. H. Comparison of Theoretical and Experimental Studies of Infrared Spectral Data for the 5-Membered Ring Heterocycles. J. Mol. Struct. 2007, 834-836, 113-128.

(51) Cao, J.; Xie, Z. -Z.; Yu, X. Excited-State Dynamics of Oxazole: A Combined Electronic Structure Calculations and Dynamic Simulations Study. Chem. Phys. 2016, 474, 25-35.

(52) Kumar, A.; Sheridan, J.; Stiefvater, O. L. The Microwave Spectrum of Oxazole I. The Complete Structure by DRM Microwave Spectroscopy. Z. Naturforsch. A 1978, 33, 145-152.

(53) Turchi, I. J.; Dewar, M. J. S. The Chemistry of Oxazoles. Chem. Rev. 1975, 75, 389-437.

(54) Han, S.; Kang, T. Y.; Choi, S.; Choi, K.-W.; Baek, S. J.; Lee, S.; Kim, S. K. One-Photon lonization Spectroscopy of Jet-Cooled Oxazole and Thiazole: The Role of Oxygen and Sulfur in the m-Conjugation of Heterocyclic Compounds. Phys. Chem. Chem. Phys. 2008, 10, 3883-3887.

(55) Palmer, M. H.; Findlay, R. H.; Egdell, R. G. The Electronic Structure of Heteroaromatic Molecules; Ab Initio Calculations and Photoelectron Spectra for the Isomeric Oxazoles and Some Oxadiazoles. J. Mol. Struct. 1977, 40, 191-210.

(56) Culberson, L. M.; Blackstone, C. C.; Wysocki, R.; Sanov, A. Selective Deprotonation of Oxazole and Photoelectron Imaging of the Oxazolide Anion. Phys. Chem. Chem. Phys. 2014, 16, 527-532.

(57) Mátyus, P.; Fuji, K.; Tanaka, K. Density Functional Calculations on Heterocyclic Compounds. Part 1. Studies of Protonation of 5- and 6-Membered Nitrogen Heterocyclics. Tetrahedron 1994, 50, 2405-2414.

(58) Jursic, B. S. Density Functional Theory Study of Ethene and Acetylene Addition to Oxazole and Protonated Oxazole. J. Chem. Soc. Perkin Trans. 2 1996, 1021-1026.

(59) Hunter, E. P. L.; Lias, S. G. Evaluated Gas Phase Basicities and Proton Affinities of Molecules: An Update. J. Phys. Chem. Ref. Data 1998, 27, 413-656.

(60) Chatterjee, K.; Dopfer, O. Unraveling the Protonation Site of Oxazole and Solvation with Hydrophobic Ligands by Infrared Photodissociation Spectroscopy. Phys. Chem. Chem. Phys. 2019, 21, 15157-15166.

(61) Dopfer, O. Spectroscopic and Theoretical Studies of $\mathrm{CH}_{3}{ }^{+}-\mathrm{Rg}_{n}$ Clusters (Rg=He, $\mathrm{Ne}$, Ar): From Weak Intermolecular Forces to Chemical Reaction Mechanisms. Int. Rev. Phys. Chem. 2003, 22, 437-495.

(62) Dopfer, O. IR Spectroscopy of Microsolvated Aromatic Cluster lons: Ionization-Induced Switch in Aromatic Molecule-Solvent Recognition. Z. Phys. Chem. 2005, 219, 125-168.

(63) Frisch, M. J. et al. Gaussian 09, D.01, Gaussian, Inc., Wallingford, CT, USA 2009.

(64) Chatterjee, K.; Matsumoto, Y.; Dopfer, O. Aromatic Charge Resonance Interaction Probed by Infrared Spectroscopy. Angew. Chem. Int. Ed. 2019, 58, 3351-3355.

(65) Chatterjee, K.; Dopfer, O. Infrared Signatures of Protonated Benzonitrile. Astrophys. J. 2018, 865, 114.

(66) Klyne, J.; Dopfer, O. Microhydration of Protonated 5-Hydroxyindole Revealed by Infrared Spectroscopy. Phys. Chem. Chem. 
Phys. 2019, 21, 2706-2718.

(67) Klyne, J.; Miyazaki, M.; Fujii, M.; Dopfer, O. Sequential Microhydration of Cationic 5-Hydroxyindole $\left(5 \mathrm{HI}^{+}\right)$: Infrared Photodissociation Spectra of $5 \mathrm{HI}^{+}-\mathrm{W}_{n}$ Clusters $\left(\mathrm{W}=\mathrm{H}_{2} \mathrm{O}, n \leq 4\right)$. Phys. Chem. Chem. Phys. 2018, 20, 3092-3108.

(68) Chatterjee, K.; Dopfer, O. Microhydration of $\mathrm{PAH}^{+}$Cations: Evolution of Hydration Network in Naphthalene ${ }^{+}-\left(\mathrm{H}_{2} \mathrm{O}\right)_{n} \mathrm{Clusters}$

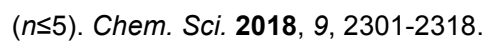

(69) Schütz, M.; Matsumoto, Y.; Bouchet, A.; Öztürk, M.; Dopfer, O. Microsolvation of the Pyrrole Cation ( $\left.\mathrm{Py}^{+}\right)$with Nonpolar and Polar Ligands: Infrared Spectra of $\mathrm{Py}^{+}-\mathrm{L}_{n}$ with $\mathrm{L}=\mathrm{Ar}, \mathrm{N}_{2}$, and $\mathrm{H}_{2} \mathrm{O}(n \leq 3)$. Phys. Chem. Chem. Phys. 2017, 19, 3970-3986.

(70) Rocher-Casterline, B. E.; Ch'ng, L. C.; Mollner, A. K.; Reisler, H. Communication: Determination of the Bond Dissociation Energy $\left(D_{0}\right)$ of the Water Dimer, $\left(\mathrm{H}_{2} \mathrm{O}\right)_{2}$, by Velocity Map Imaging. J. Chem. Phys. 2011, 134, 211101.

(71) Herzberg, G. Molecular Spectra and Molecular Structure. II. Infrared and Raman Spectra of Polyatomic Molecules; Krieger Publishing Company, Malabar, Florida, 1991.

(72) Glendening, E. D.; Badenhoop, J. K.; Reed, A. E.; Carpenter, J. E.; Bohmann, J. A.; Morales, C. M.; Landis, C. R.; Weinhold, F. NBO 6.0, Theoretical Chemistry. University of Wisconsin, Madison 2013.

(73) Reed, A. E.; Curtiss, L. A.; Weinhold, F. Intermolecular Interactions from a Natural Bond Orbital, Donor-Acceptor Viewpoint. Chem. Rev. 1988, 88, 899-926.

(74) Contreras-García, J.; Johnson, E. R.; Keinan, S.; Chaudret, R.; Piquemal, J. P.; Beratan, D. N.; Yang, W. NCIPLOT: A Program for Plotting Noncovalent Interaction Regions. J. Chem. Theory Comput. 2011, 7, 625-632.

(75) Johnson, E. R.; Keinan, S.; Mori Sánchez, P.; Contreras García, J.; Cohen, A. J.; Yang, W. NCl: Revealing Non-Covalent Interactions. J. Am. Chem. Soc. 2010, 132, 6498-6506.

(76) Császár, A. G.; Czakó, G.; Furtenbacher, T.; Tennyson, J.; Szalay, V.; Shirin, S. V.; Zobov, N. F.; Polyansky, O. L. On Equilibrium Structures of the Water Molecule. J. Chem. Phys. 2005, 122, 214305.

(77) Klyne, J.; Schmies, M.; Miyazaki, M.; Fujii, M.; Dopfer, O. Stepwise Microhydration of Aromatic Amide Cations: Water Solvation Networks Revealed by the Infrared Spectra of Acetanilide ${ }^{+}-\left(\mathrm{H}_{2} \mathrm{O}\right)_{n}$ Clusters $(n \leq 3)$. Phys. Chem. Chem. Phys. 2018, 20, 31483164.

(78) Klyne, J.; Schmies, M.; Fujii, M.; Dopfer, O. Stepwise Microhydration of Aromatic Amide Cations: Formation of Water Solvation Network Revealed by Infrared Spectra of Formanilide ${ }^{+}-\left(\mathrm{H}_{2} \mathrm{O}\right)_{n}$ Clusters $(n \leq 5)$. J. Phys. Chem. B 2015, 119, 1388-1406.

(79) Goebbert, D. J.; Wenthold, P. G. Water Dimer Proton Affinity from the Kinetic Method: Dissociation Energy of the Water Dimer. Eur. J. Mass Spectrom. 2004, 10, 837-845.

(80) Kuyanov-Prozument, K.; Choi, M. Y.; Vilesov, A. F. Spectrum and Infrared Intensities of OH-Stretching Bands of Water Dimers. J. Chem. Phys. 2010, 132, 14304.

(81) Huisken, F.; Kaloudis, M.; Kulcke, A. Infrared Spectroscopy of Small Size-selected Water Clusters. J. Chem. Phys. 1996, 104, $17-25$.

(82) Huang, Z. S.; Miller, R. E. High-resolution Near-infrared Spectroscopy of Water Dimer. J. Chem. Phys. 1989, 91, 6613-6631.

(83) Courty, A.; Mons, M.; Le Calvé, J.; Piuzzi, F.; Dimicoli, I. Chemistry of Aromatic Cations on Water Clusters: Magic Numbers as a Mass Spectroscopic Diagnosis of Reactivity. J. Phys. Chem. A 1997, 101, 1445-1450.

(84) Bing, D.; Hamashima, T.; Tsai, C.-W.; Fujii, A.; Kuo, J.-L. Proton Location in $\left(\mathrm{CH}_{3}\right)_{3} \mathrm{~N}-\mathrm{H}^{+}-\left(\mathrm{CH} \mathrm{H}_{3} \mathrm{OH}\right)_{n}$ : A Theoretical and Infrared Spectroscopy Study. Chem. Phys. 2013, 421, 1-9.

(85) Chatterjee, K.; Dopfer, O. Infrared Spectroscopy Hydrated Polycyclic Aromatic Hydroarbon Cations: Naphthalene+-Water. Phys. Chem. Chem. Phys. 2017, 19, 32262-32271.

(86) Cheng, T. C.; Bandyopadhyay, B.; Mosley, J. D.; Duncan, M. A. IR Spectroscopy of Protonation in Benzene-Water Nanoclusters: Hydronium, Zundel, and Eigen at a Hydrophobic Interface. J. Am. Chem. Soc. 2012, 134, 13046-13055. 
(87) Kryachko, E. S.; Nguyen, M. T. Low Energy Barrier Proton Transfer in Protonated Benzene-Water Complex. J. Phys. Chem. A 2001, 105, 153-155.

(88) Solcà, N.; Dopfer, O. IR Spectrum of the Benzene-Water Cation: Direct Evidence for a Hydrogen-Bonded Charge-Dipole Complex. Chem. Phys. Lett. 2001, 347, 59-64.

(89). Tanabe, K.; Miyazaki, M.; Schmies, M.; Patzer, A.; Schütz, M.; Sekiya, H.; Sakai, M.; Dopfer, O.; Fujii, M. Watching Water Migration around a Peptide Bond. Angew. Chem. Int. Ed. 2012, 51, 6604-6607.

(90) Nakamura, T.; Schmies, M.; Patzer, A.; Miyazaki, M.; Ishiuchi, S.; Weiler, M.; Dopfer, O.; Fujii, M. Solvent Migration in Microhydrated Aromatic Aggregates: Ionization-Induced Site Switching in the 4-Aminobenzonitrile Water Cluster. Chem. Eur. J. 2014, 20, 2031-2039.

(91) Wohlgemuth, M.; Miyazaki, M.; Weiler, M.; Sakai, M.; Dopfer, O.; Fujii, M.; Mitrić, R. Solvation Dynamics of a Single Water Molecule Probed by Infrared Spectra-Theory Meets Experiment. Angew. Chem. Int. Ed. 2014, 54, 14601-14604.

(92) Wohlgemuth, M.; Miyazaki, M.; Tsukada, K.; Weiler, M.; Dopfer, O.; Fujii, M.; Mitrić, R. Deciphering Environment Effects in Peptide Bond Solvation Dynamics by Experiment and Theory. Phys. Chem. Chem. Phys. 2017, 19, 22564-22572. 


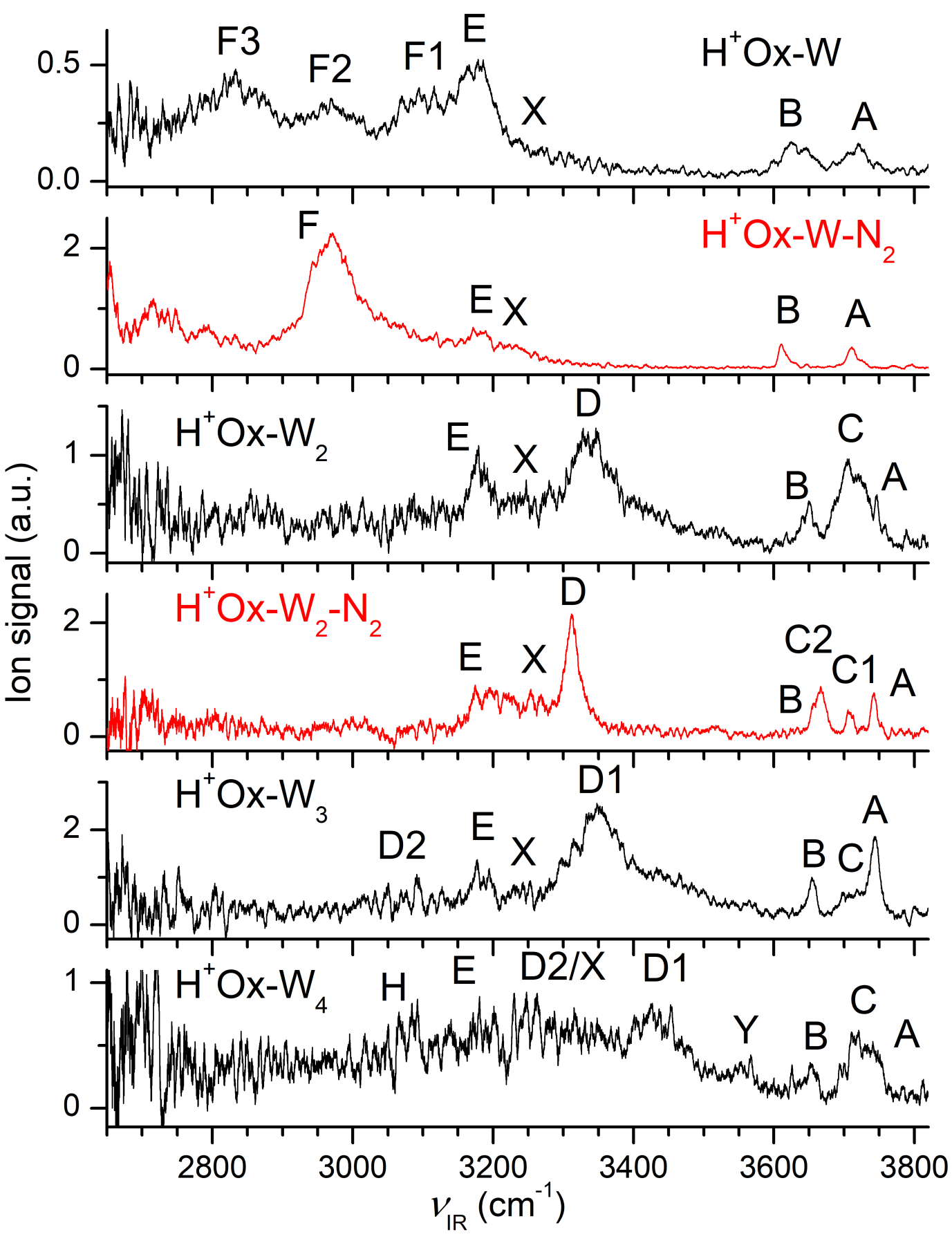


$\mathrm{H}^{+} \mathrm{Ox}$

1.0778

1.0745

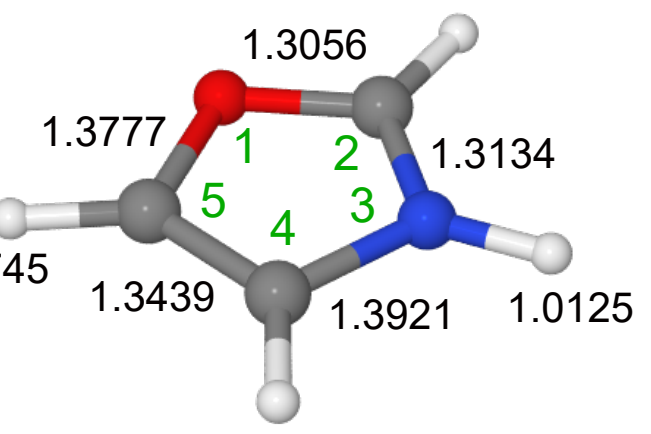

1.0748

$\mathrm{H}^{+} \mathrm{Ox}-\mathrm{W}(\mathrm{H})$

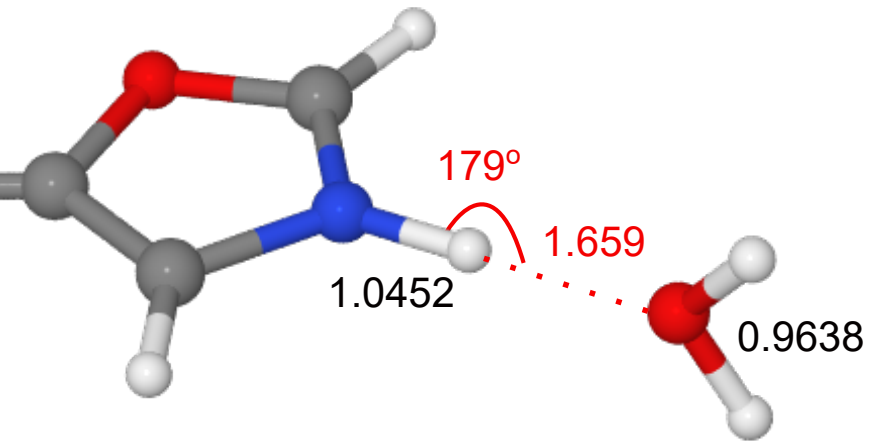

$6094(0,0)$

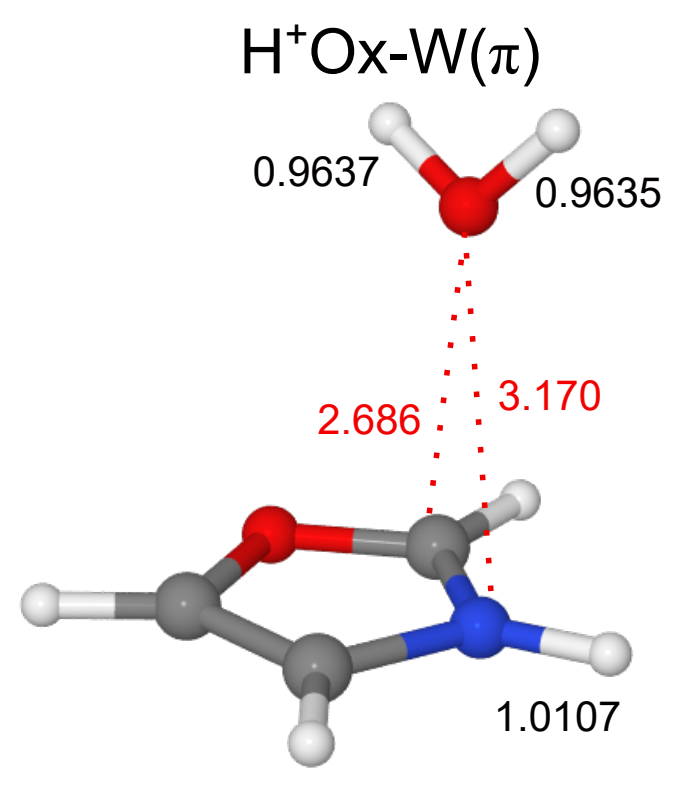

3334 (2759, 2536)

$\mathrm{H}^{+} \mathrm{Ox}-\mathrm{W}(\mathrm{H})-\mathrm{N}_{2}(\mathrm{H})$

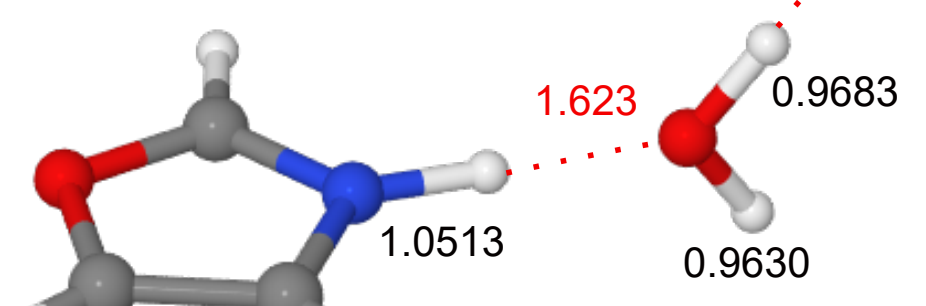

$937(0,0)$

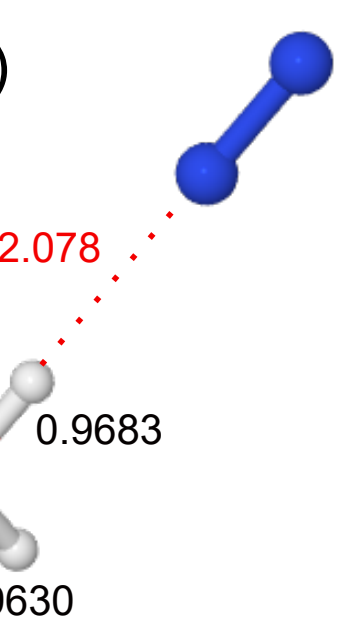

$\mathrm{H}^{+} \mathrm{Ox}-\mathrm{W}(\mathrm{H})-\mathrm{N}_{2}(\pi)$

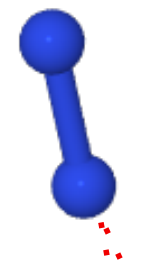

$3.145: \therefore 3.310$

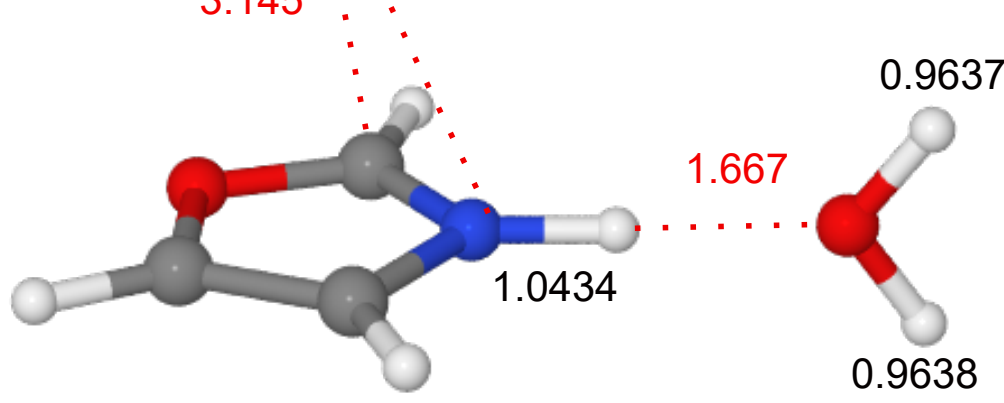

$766(171,766)$ 

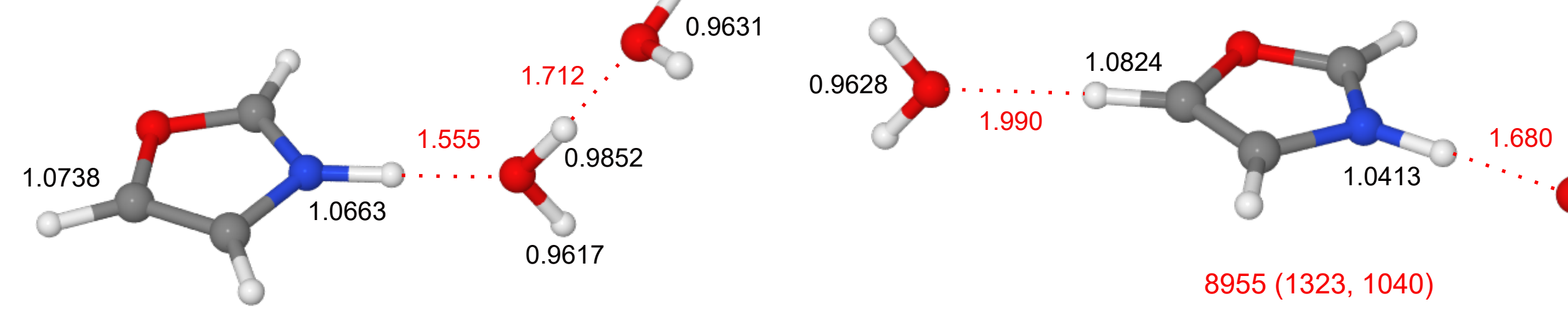

0.9636

$8955(1323,1040)$

$10278(0,0)$

$\mathrm{H}^{+} \mathrm{Ox}-\mathrm{W}_{2}(\mathrm{H})-\mathrm{N}_{2}(\mathrm{H} 1)$

0.9630

0.9629

1.726 0.9831

1.0742

$789(0,0)$

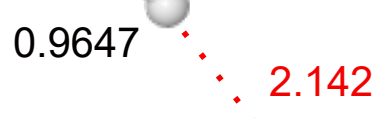

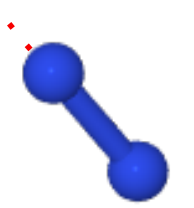

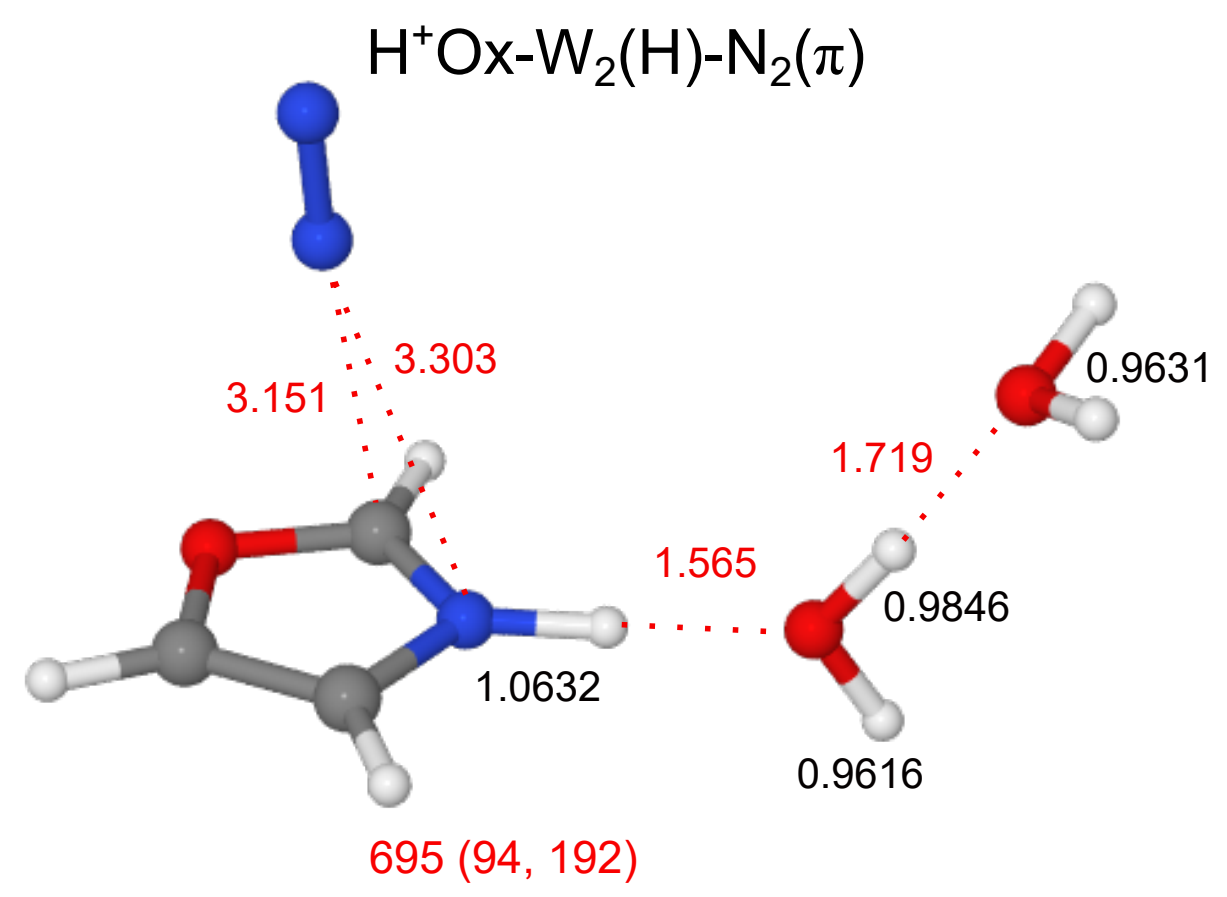

$\mathrm{H}^{+} \mathrm{Ox}-\mathrm{W}_{2}(\mathrm{H})-\mathrm{N}_{2}(\mathrm{H} 2)$ 0.9625

\subsection{7}

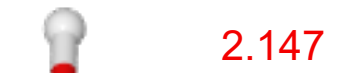

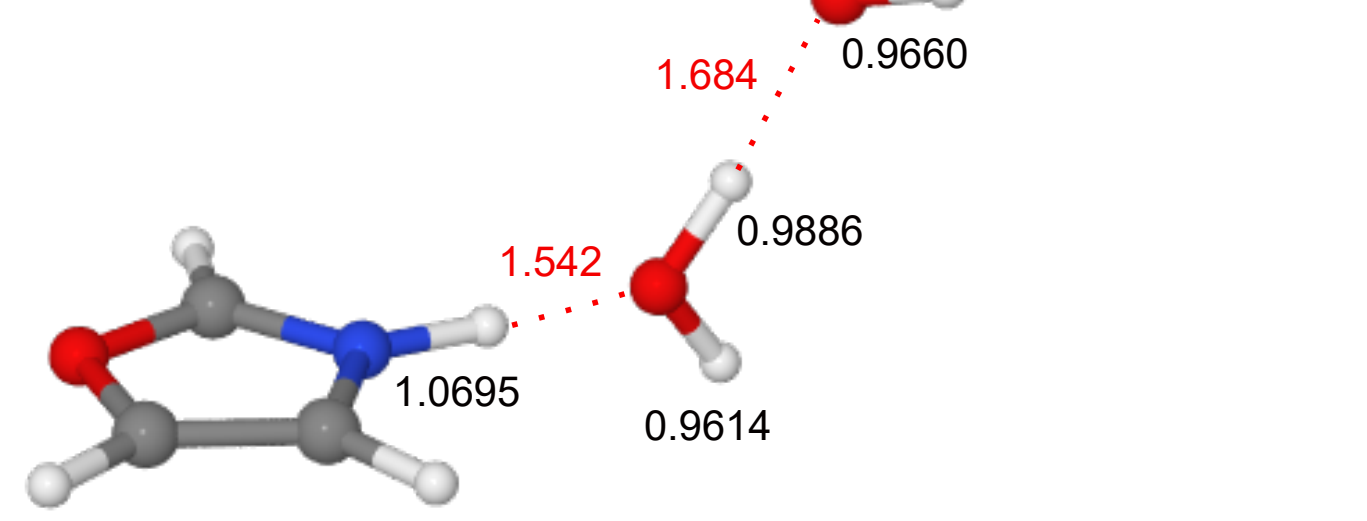

$694(95,84)$

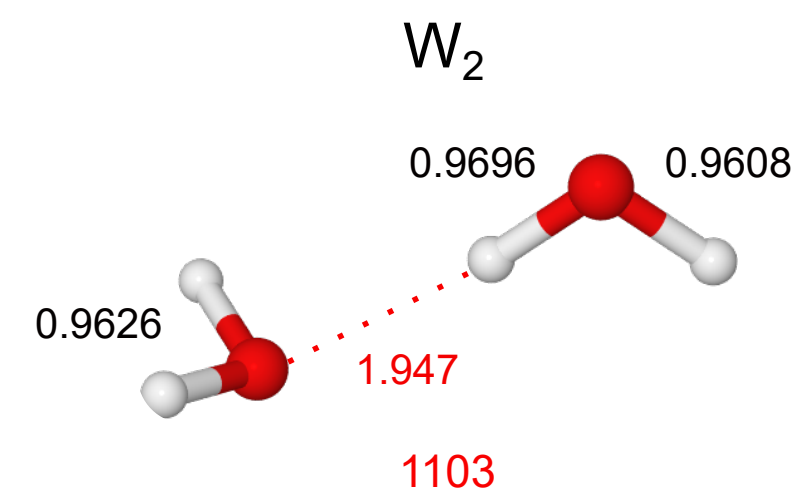

1103 


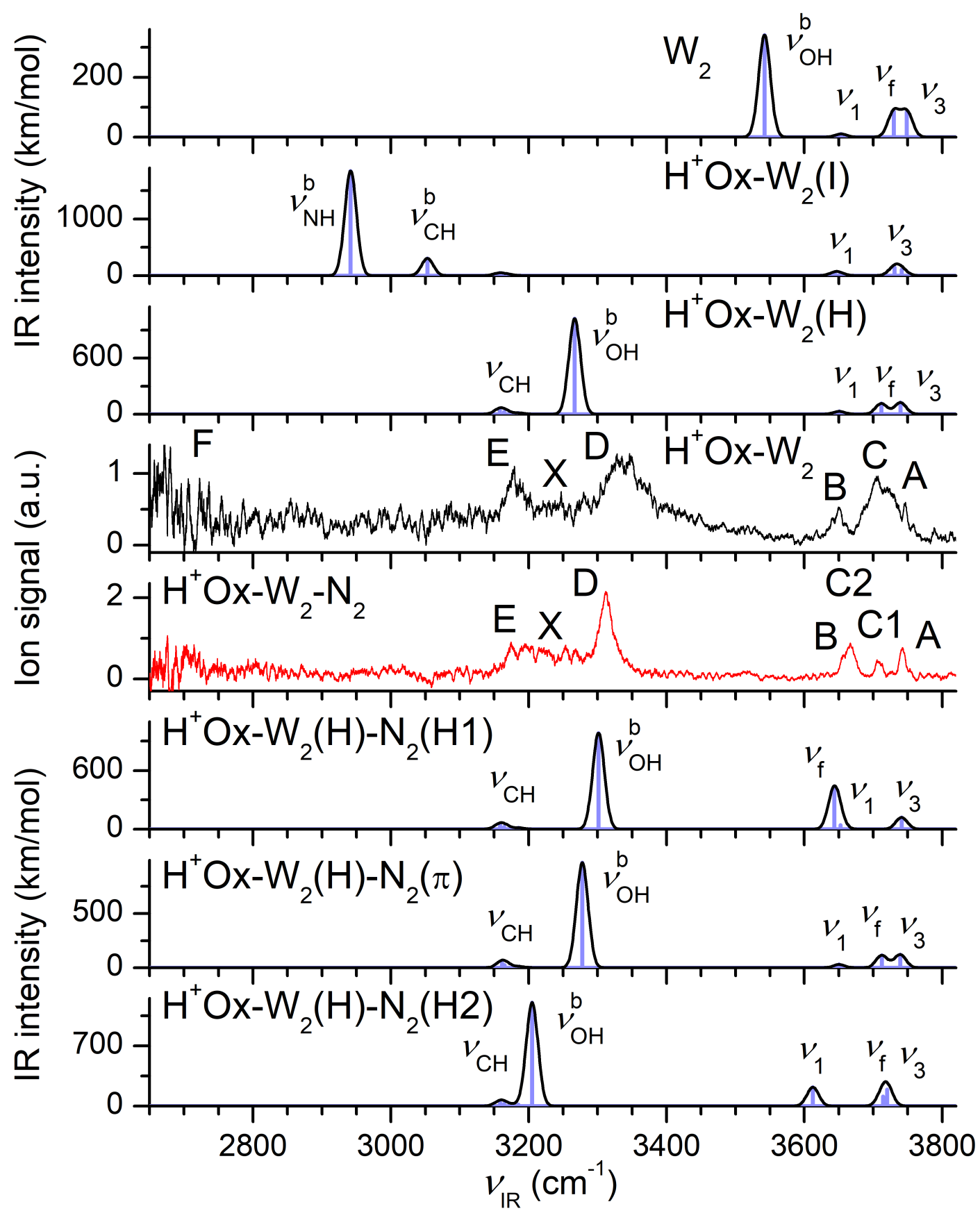




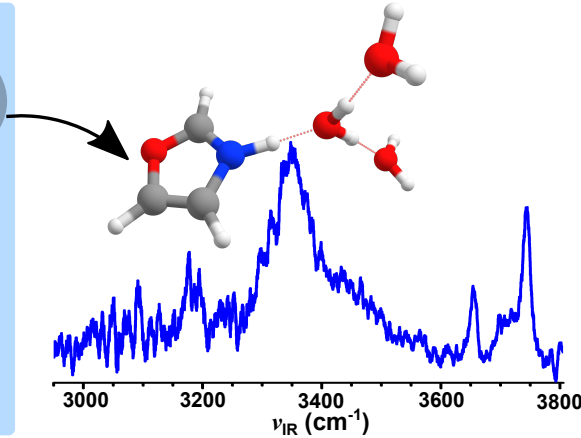




\title{
Supporting Information
}

\section{Microhydration Structures of Protonated Oxazole}

\author{
Kuntal Chatterjee and Otto Dopfer* \\ Institut für Optik und Atomare Physik, TU Berlin, Hardenbergstr. 36, 10623 Berlin, Germany \\ *Corresponding author: dopfer@physik.tu-berlin.de
}

\section{Figure Captions}

Figure S1. Optimized structure of the neutral Ox-W dimer and its linear IR absorption spectrum calculated at the B3LYP-D3/aug-cc-pVTZ level. Binding energy $\left(D_{0}\right)$ and bond lengths are given in $\mathrm{cm}^{-1}$ and $\AA$, respectively.

Figure S2. NBO atomic charge distribution (in e) of selected $\mathrm{H}^{+} \mathrm{Ox}-\mathrm{W}_{n \leq 4}$ structures obtained at the B3LYP-D3/aug-cc-pVTZ level.

Figure S3. Potential energy barrier $\left(E_{\mathrm{e}}\right)$ for internal rotation of the $W$ ligand in $\mathrm{H}^{+} \mathrm{Ox}-\mathrm{W}(\mathrm{H})$ calculated at the B3LYP-D3/aug-cc-pVTZ level in $\mathrm{cm}^{-1}$. Bond lengths are given in $\AA$.

Figure S4. Optimized structure and linear IR absorption spectrum of the $\mathrm{H}^{+} \mathrm{Ox}-\mathrm{W}(\mathrm{C} 5)$ isomer calculated at the B3LYP-D3/aug-cc-pVTZ level. Binding energy $\left(D_{0}\right)$ and bond lengths are given in $\mathrm{cm}^{-1}$ and $\AA$, respectively. Numbers in parentheses correspond to relative energies and free energies $\left(E_{0}, G_{0}\right)$ with respect to $\mathrm{H}^{+} \mathrm{Ox}-\mathrm{W}(\mathrm{H})$ in $\mathrm{cm}^{-1}$.

Figure S5. Potential energy barrier $\left(E_{e}\right)$ between $\mathrm{H}^{+} \mathrm{Ox}-\mathrm{W}_{4}(\mathrm{~b})$ and $\mathrm{Ox}-\mathrm{H}^{+} \mathrm{W}_{4}(1)$ evaluated at the B3LYP-D3/aug-cc-pVTZ level in $\mathrm{cm}^{-1}$.

Figure S6. Orbital interaction between the $\sigma^{*}$ orbital of the $X-H$ bond $(X=N / O / C)$ and the lone pair of $O$ involved in the $\mathrm{XH} \ldots \mathrm{O} \mathrm{H}$-bonds of selected $\mathrm{H}^{+} \mathrm{Ox}-\mathrm{W}_{n \leq 4}$ isomers obtained from the $\mathrm{NBO}$ analysis at the B3LYP-D3/aug-cc-pVTZ level. $E^{(2)}$ values given in $\mathrm{kJ} / \mathrm{mol}$.

Figure S7. Visualization of the $\mathrm{NCl}$ analysis of the $\mathrm{XH} \ldots \mathrm{O}(\mathrm{X}=\mathrm{N} / \mathrm{O} / \mathrm{C}) \mathrm{H}$-bonds in selected $\mathrm{H}^{+} \mathrm{OX}-\mathrm{W}_{n \leq 4}$ isomers calculated at the B3LYP-D3/aug-cc-pVTZ level. $\rho^{*}$ values for the $\mathrm{H}$-bonds are given in a.u.

Figure S8. Experimental proton affinities of $\mathrm{W}_{n}$ clusters $(n=1-4)$ and $\mathrm{Ox}$. 


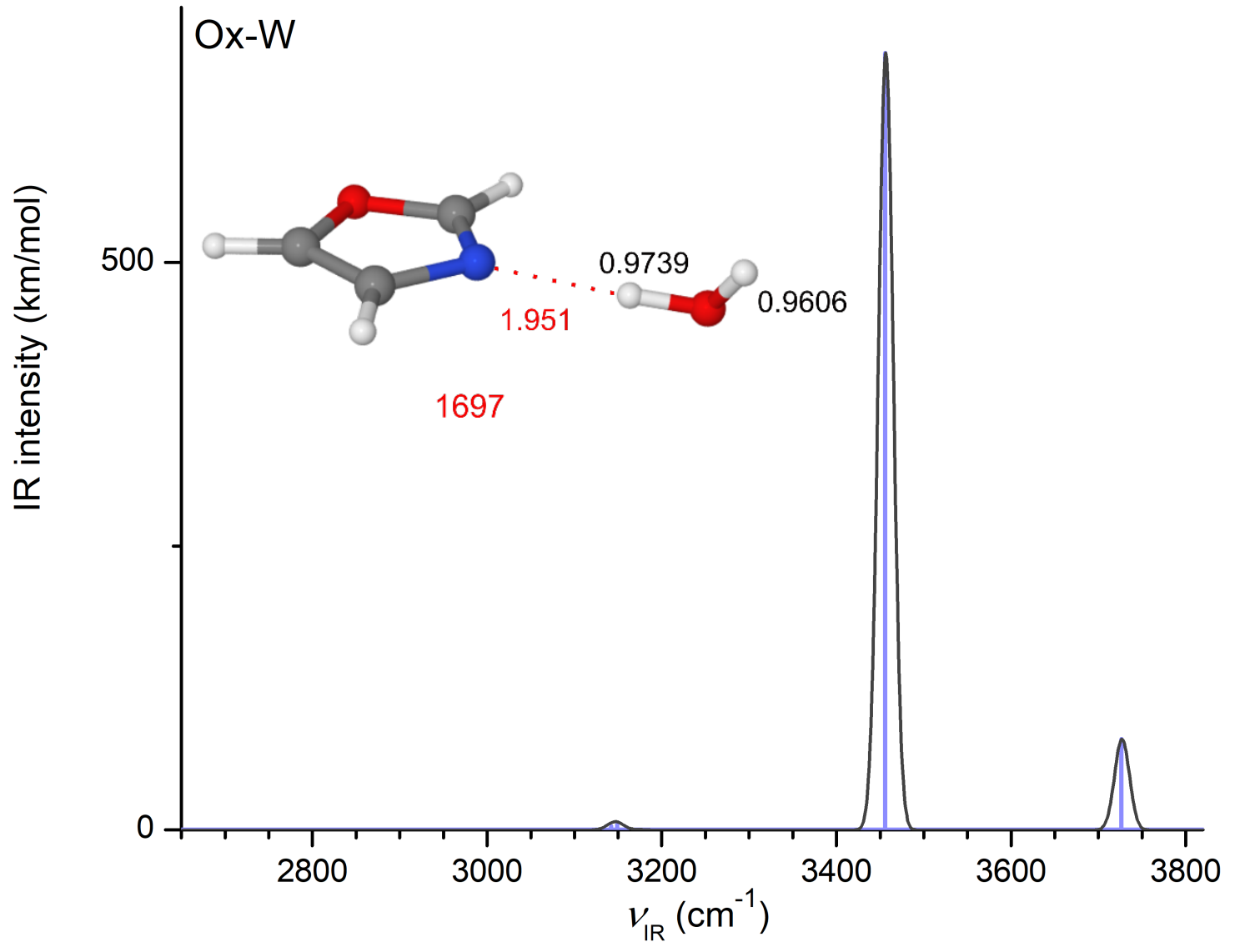

Figure S1 


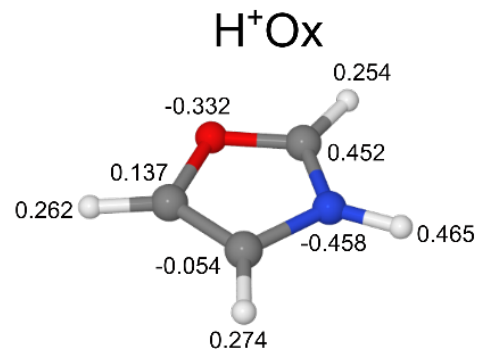

$\mathrm{H}^{+} \mathrm{Ox}-\mathrm{W}_{2}$
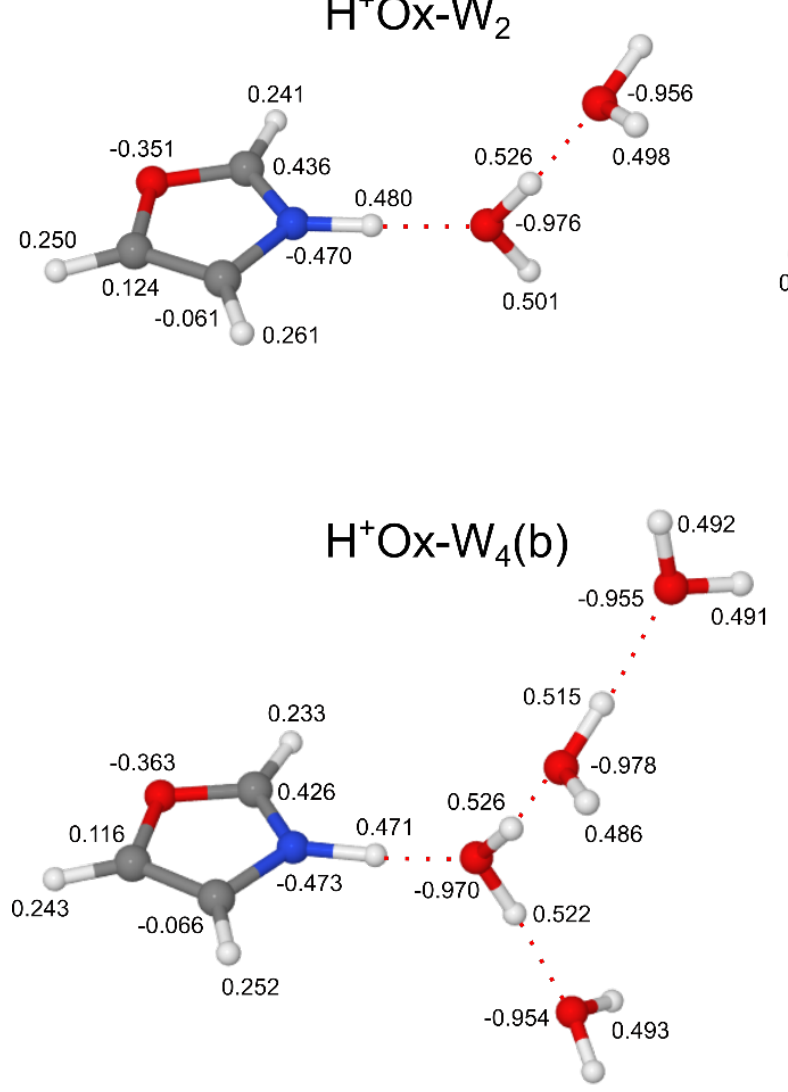
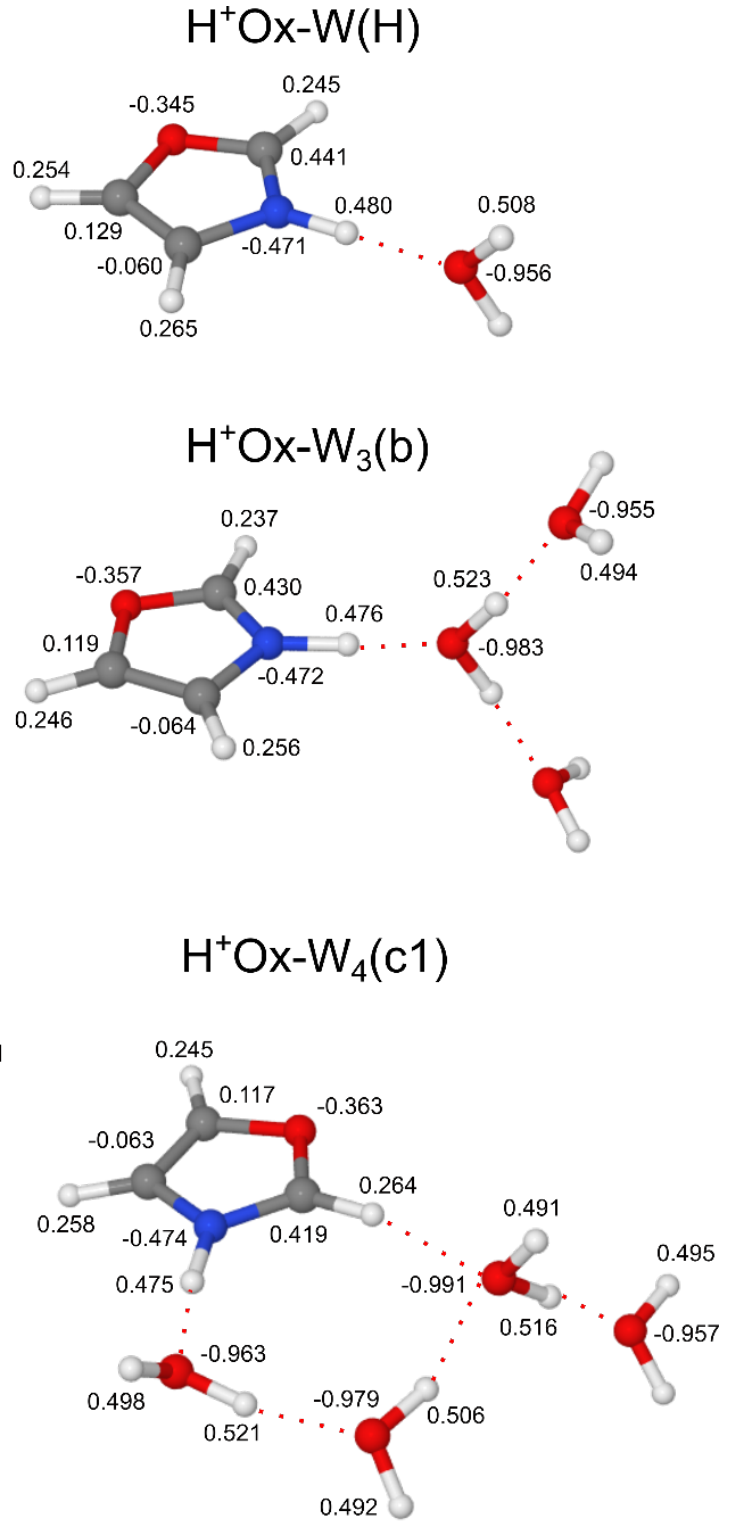

Figure S2 


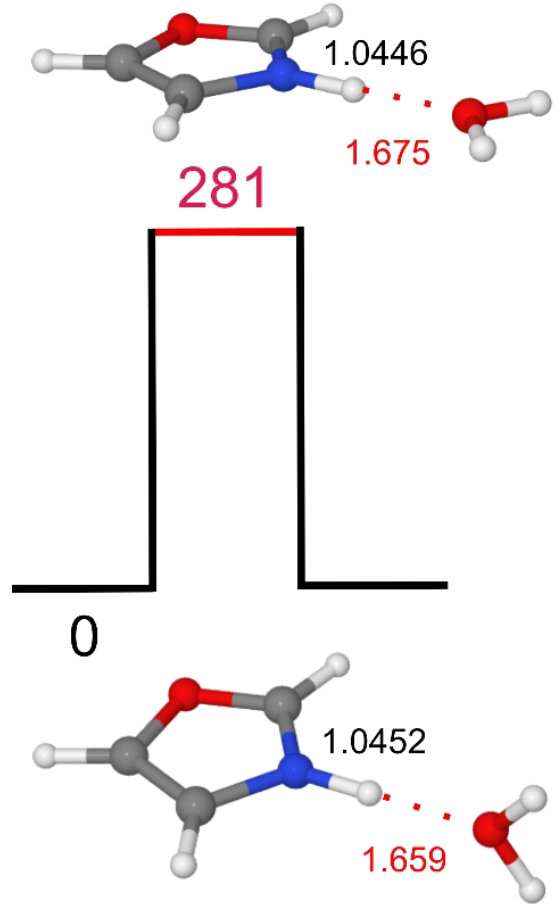

Figure S3 


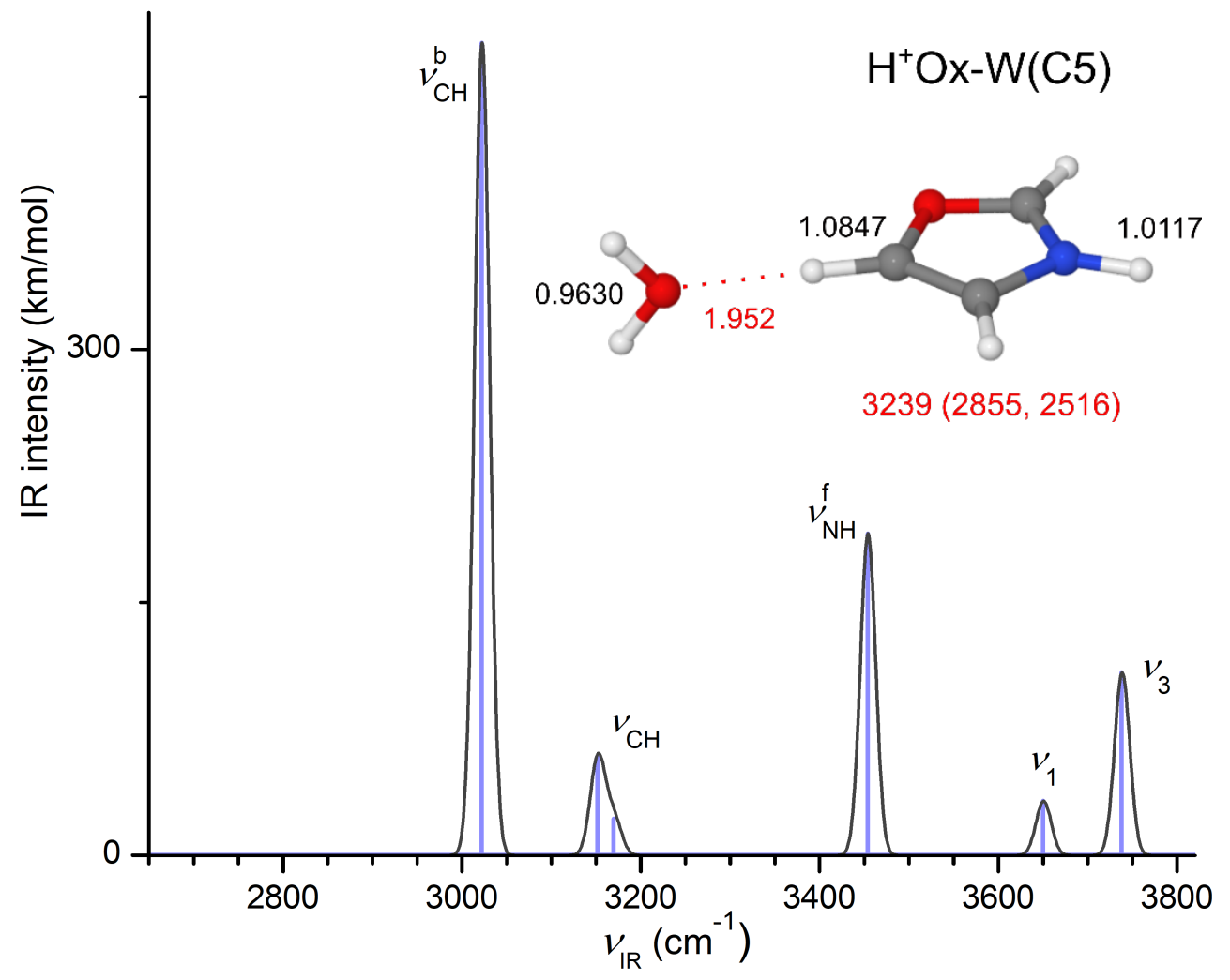

Figure S4 


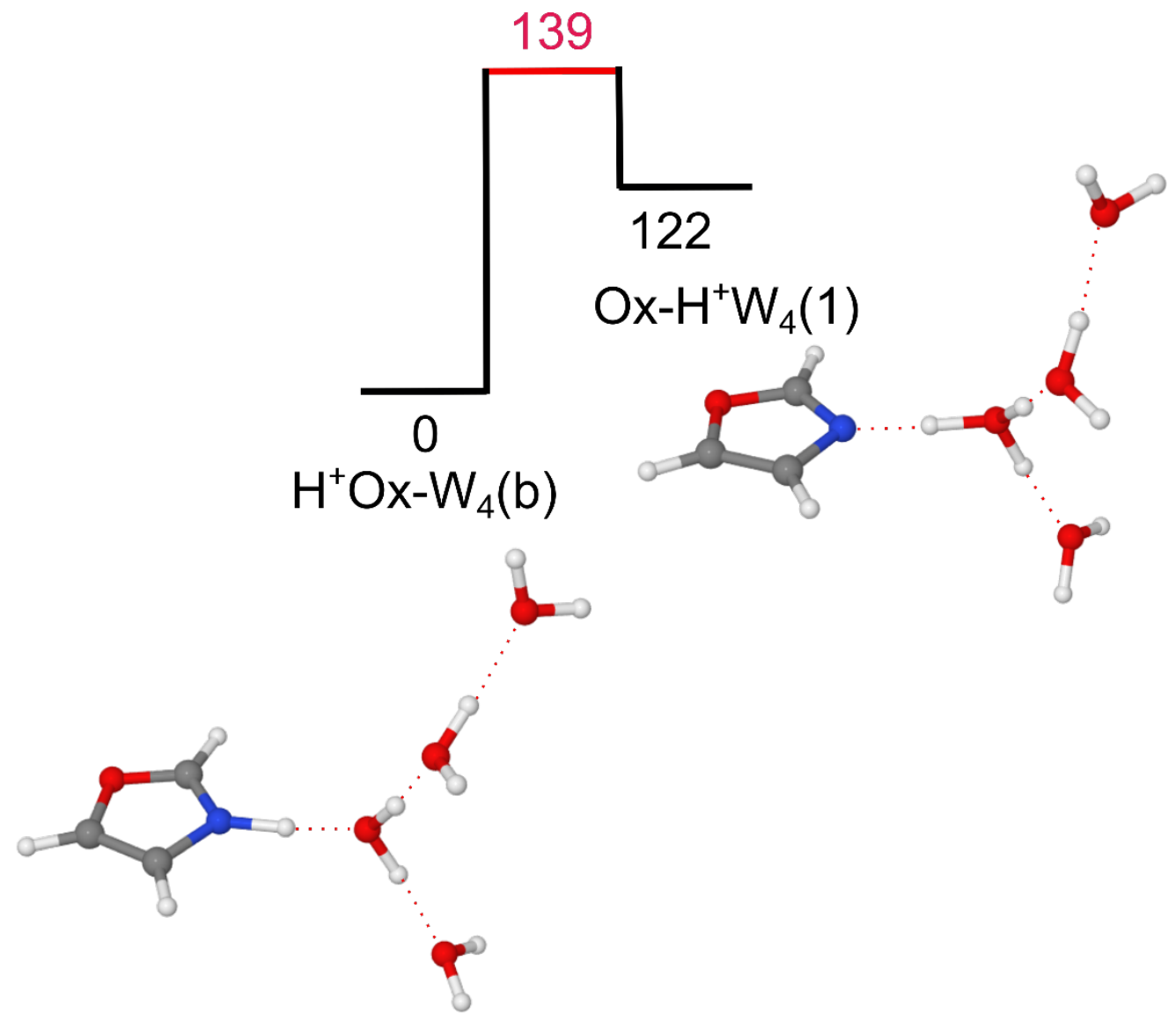

Figure S5 


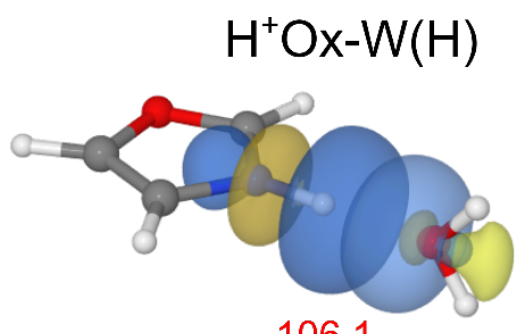

106.1
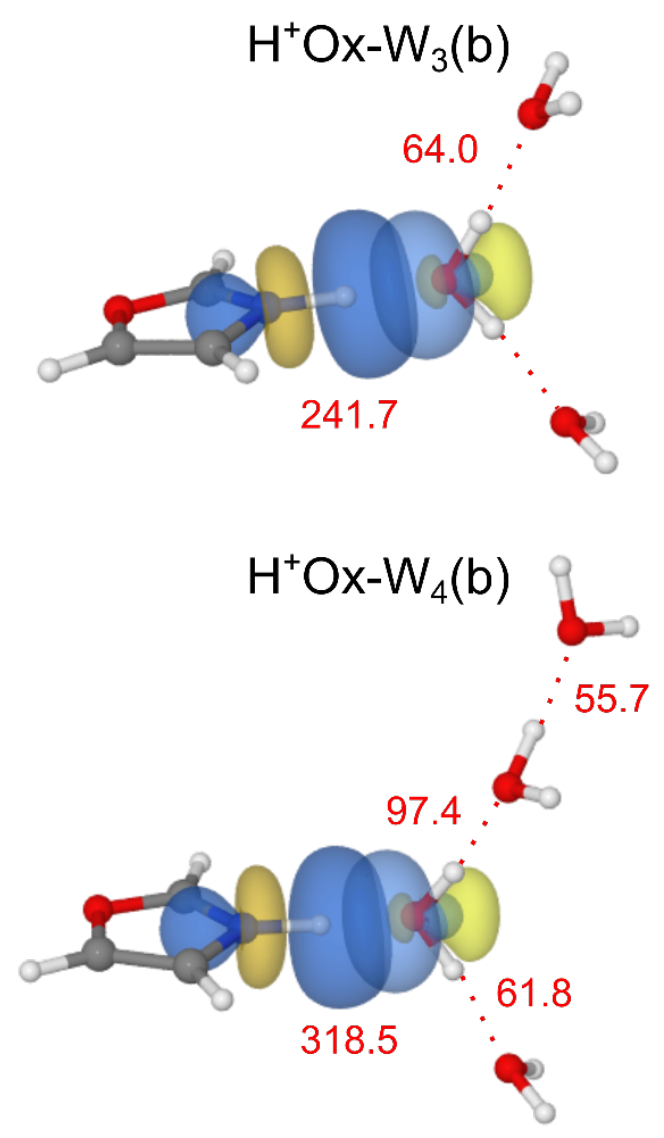
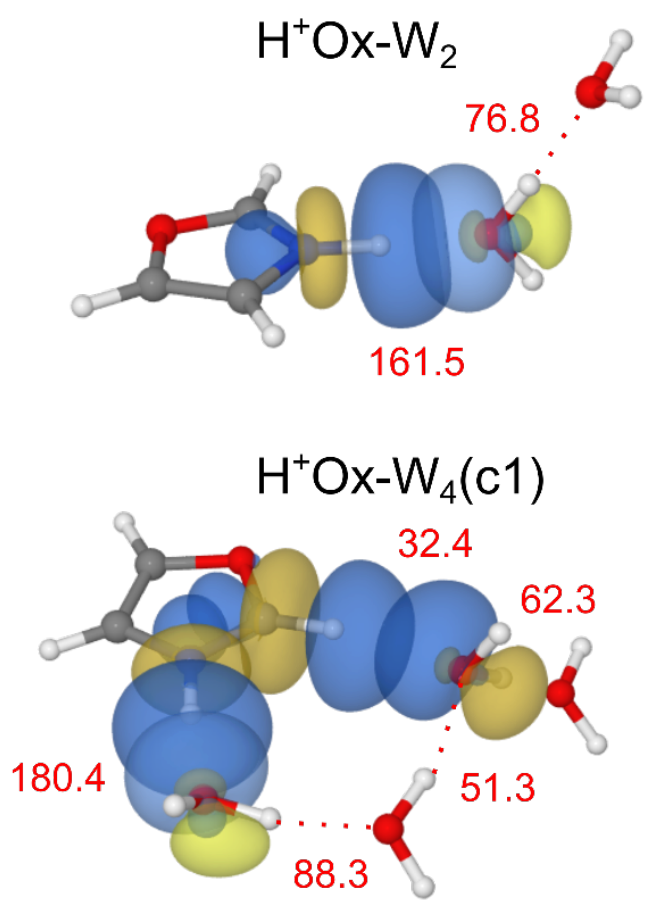

Figure S6 

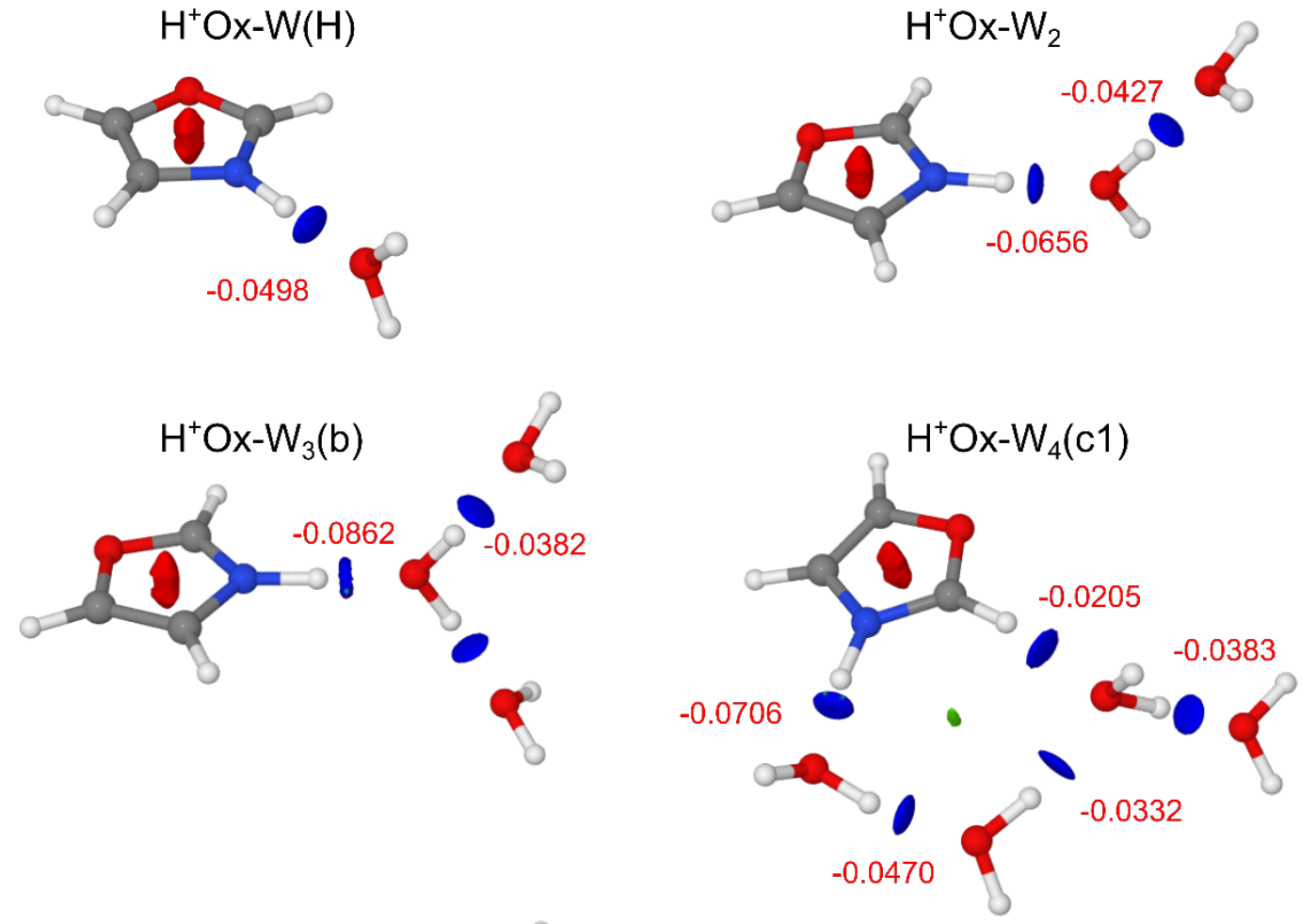

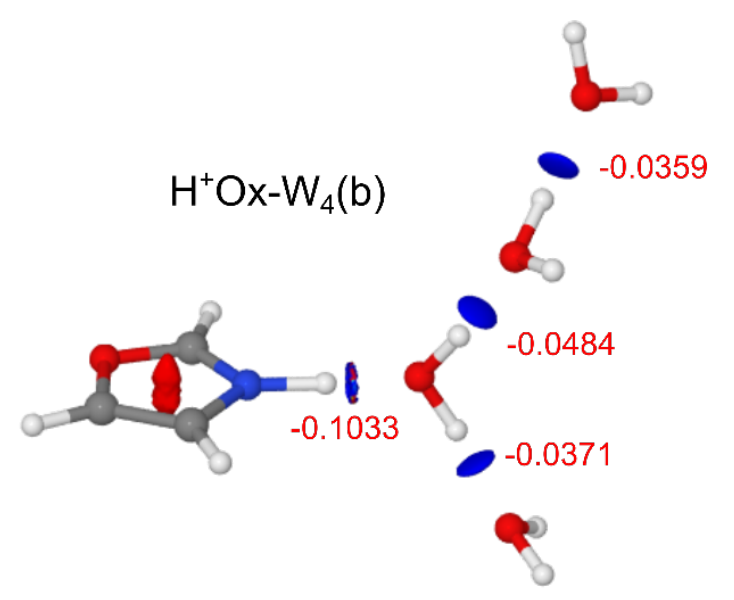

Figure S7 


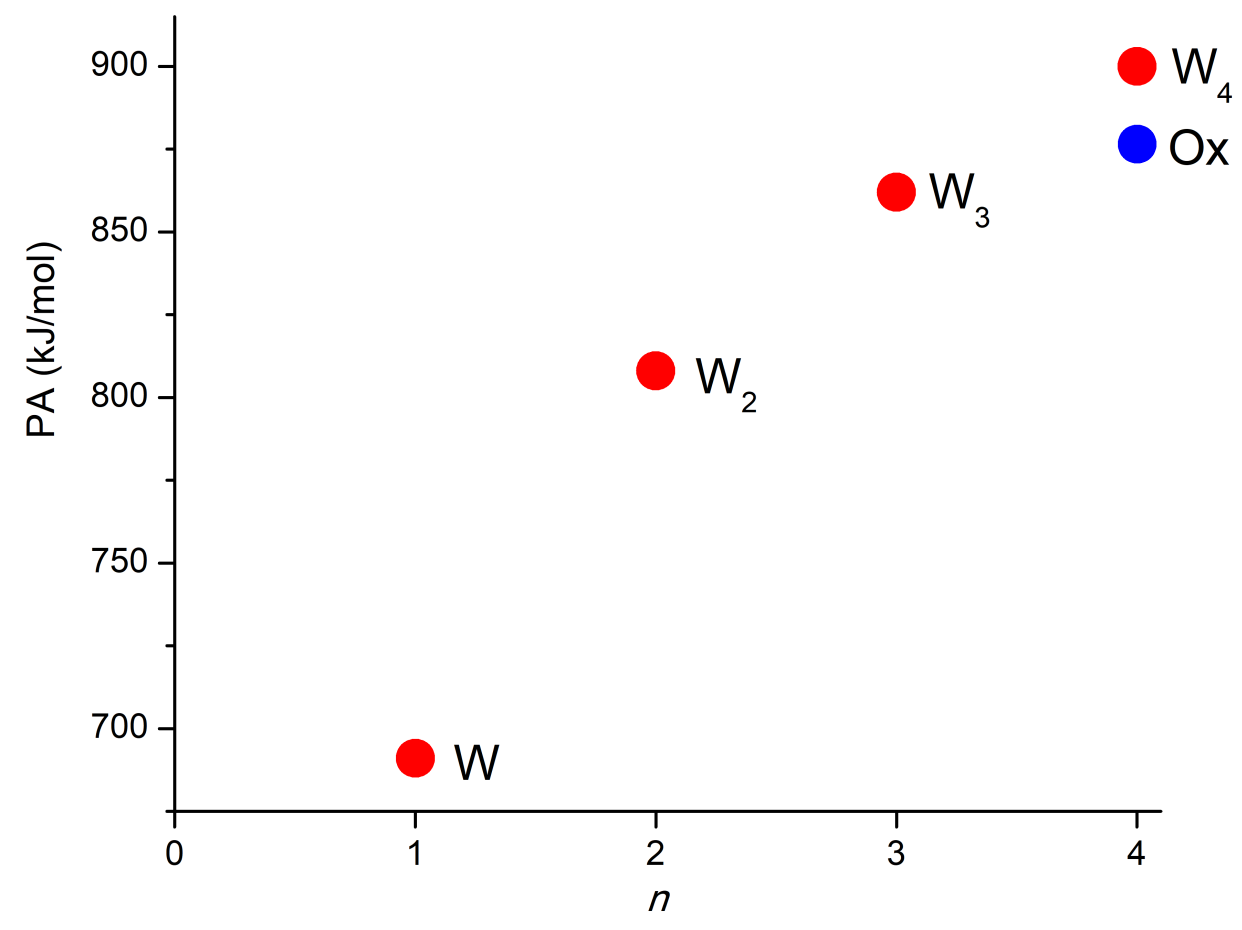

Figure S8 